Bài báo khoa học

\title{
Nghiên cứu chế độ dòng chảy khu vực bãi biển Đồi Dương, tỉnh Bình Thuận
}

\author{
Phùng Thị Mỹ Diễm ${ }^{1,2^{*}}$, Ngô Nam Thịnh ${ }^{1,2}$, Nguyễn Kỳ Phùng ${ }^{3}$ \\ 1 Trường Đại học Tài nguyên và Môi trường TP. HCM; diemptm@hcmunre.edu.vn; \\ nnthinh@hcmunre.edu.vn \\ 2 Trường Đại học Khoa học Tự nhiên, Đại học Quốc gia Hồ Chí Minh; \\ 3 Sở Khoa học và Công nghệ Tp. HCM; kyphungng@gmail.com \\ * Tác giả liên hệ: diemptm@hcmunre.edu.vn; Tel.: +84-902804525
}

Ban Biên tập nhận bài: 7/1/2021; Ngày phản biện xong: 23/2/2021; Ngày đăng bài: $25 / 3 / 2021$

Tóm tắt: Mô hình phổ sóng Mike $21 \mathrm{SW}$ (Spectral Waves) và mô hình thủy lực Mike 21 HD FM (Hydro Dynamic Flow Model) được sử dụng trong bài báo để tính toán trường sóng và dòng chảy ven bờ khu vực bãi biển Đồi Dương, Phan Thiết, tỉnh Bình Thuận. Mô hình sóng Mike $21 \mathrm{SW}$ và Mike $21 \mathrm{HD} F M$ đều được hiệu chỉnh và kiểm định với số liệu thực đo với hệ số tương quan khá tốt. Kết quả tính toán trường sóng là điều kiện đầu vào cho mô hình tính dòng chảy tổng hợp Mike 21 HD FM. Kết quả tính toán trường sóng khu vực bãi biển Đồi Dương cho thấy độ cao sóng có nghĩa vào mùa gió Đông Bắc khoảng $0,9-1,3 \mathrm{~m}$, với hướng sóng là hướng Đông Bắc, vào mùa gió Tây Nam khoảng $0,4-0,7 \mathrm{~m}$ với hướng sóng là hướng Tây Nam. Đối với vận tốc dòng chảy, kết quả tính toán cho thấy vận tốc dòng chảy ven biển Đồi Dương khá nhỏ, đạt khoảng $0,025-0,35 \mathrm{~m} / \mathrm{s}$ vào mùa gió Tây Nam và $0,02-0,3 \mathrm{~m} / \mathrm{s}$ đối với mùa gió Đông Bắc. Qua kết quả phân tích thấy được dòng chảy khu vực bãi biển Đồi Dương chịu ảnh hưởng mạnh bởi triều. Nghiên cứu cũng làm cơ sở đưa ra các giải pháp nhằm giảm thiểu các quá trình tác động tiêu cực đến vùng bờ biển do ảnh hưởng của dòng chảy gây ra, góp phần định hướng phát triển kinh tế xã hội trong khu vực nghiên cứu.

Từ khóa: Mike 21 SW; Mike 21 HD FM; Dòng chảy tổng hợp; Sóng; Bãi biển Đồi Dương.

\section{Mở đầu}

Với đường bờ biển dài $192 \mathrm{~km}$, tỉnh Bình Thuận có nguồn tài nguyên du lịch phong phú gắn với biển, rừng và đảo [1]; nhiều bãi biển đẹp, nhiều khu bảo tồn thiên nhiên cấp quốc gia như Núi Ông, núi Tà Cú, khu bảo tồn biển đảo Phú Quý, Cù Lao Cau đa dạng sinh học; có cảnh quan đặc trưng nổi tiếng như đồi cát bay Mũi Né, Bàu Trắng, Mũi Kê Gà, các hồ thác thủy điện, suối khoáng nóng Vĩnh Hảo, Đa Kai..., hệ thống đường giao thông, khu neo đậu tàu thuyền, các công trình hạ tầng cơ sở của ngành du lịch, thủy sản, sản xuât muối... nằm tiếp giáp với bờ biển, thậm chí giáp với mép nước biển. Song, đó cũng là gánh nặng trong việc đối phó với thiên tai, các tai biến môi trường, trong đó xói lở đường bờ là một trong những tai biến phổ biến nhất, ảnh hưởng mạnh mẽ tới việc phát triển đời sống kinh tế xã hội và nhu cầu phát triển du lịch. Trong vài thập niên trở lại đây, bãi biển Đồi Dương bị xói lở mạnh mẽ, các hoạt động du lịch bị ảnh hưởng nặng nề, các hoạt động kinh tế xã hội của người dân tại khu vực gần như bị tê liệt. Có rất nhiều nguyên nhân tác động đến diễn biển cửa sông, nhưng nguyên nhân chủ yếu là do tác động của sóng và dòng chảy. 
Chế độ thủy động lực ở đây có vai trò rất quan trọng trong việc vận chuyển bùn cát, biến động địa hình cũng như khả năng phát tán các chất gây ô nhiễm từ vùng ven bờ ra phía ngoài biển. Dòng chảy trong khu vực ven bờ rất phức tạp và có vai trò rất lớn trong việc vận chuyển vật chất đáy, quyết định đến xu thế vận chuyển bùn cát ven bờ gây xói lở hay bồi tụ bãi biển, vùng bờ. Chính vì vậy, đặc điểm biến động dòng chảy ở khu vực này đã được quan tâm nghiên cứu ở nhiều khía cạnh khác nhau như phân tích từ số liệu đo đạc khảo sát và mô hình toán [2-6]. Các thành phần dòng chảy chủ yếu trong đới ven bờ bao gồm dòng chảy phát sinh do sóng, dòng thủy triều, dòng chảy gió và chảy ra từ các cửa sông. Những thành phần dòng chảy tương tác với địa hình tạo ra các dạng hoàn lưu phức tạp. Các phương pháp thường dùng để mô phỏng chế độ thủy động lực ven biển dưới tác động tự nhiên và con người gồm đo đạc, khảo sát, mô hình vật lý; mô hình toán; công nghệ viễn thám và GIS.

Mô hình toán là một phương pháp hiện đại được phát triển mạnh trong mấy chục năm trở lại đây, đã được ứng dụng khá hiệu quả trong thực tế tại nước ta cũng như trên thế giới [7-10]. Việc áp dụng phương pháp này đòi hỏi phải qua nhiều bước như lựa chọn, xây dựng mô hình, hiệu chỉnh xác định thông số của mô hình và cuối cùng là ứng dụng mô hình để đánh giá, dự báo. Các mô hình toán ngày càng chứng tỏ là một công cụ mạnh và đắc lực bởi khả năng cho kết quả tính toán nhanh, phạm vi ứng dụng rộng, dễ dàng thay đổi các kịch bản bài toán, nhất là trong việc tính toán, mô phỏng các hệ thống lớn. Trong nghiên cứu này, bộ mô hình MIKE 21 của Viện Thủy Lợi Đan Mạch là công cụ chính được sử dụng để mô phỏng chế độ dòng chảy tại khu vực bãi biển Đồi Dương. Sử dụng mô đun Mike 21 HD FM để tính toán dòng chảy do gió, dòng chảy do sóng, dòng chảy do triều và dòng chảy tổng hợp, từ đó xem xét được mức độ ảnh hưởng của các yếu tố đến chế độ dòng chảy trong khu vực. Kết quả nghiên cứu có thể làm cơ sở cho việc tính toán thiết kế công trình đê chắn sóng cho cảng cũng như một số công trình phục vụ quy hoạch phát triển du lịch bãi biển Đồi Dương. Bài báo nghiên cứu chế độ dòng chảy trong phạm vi khu vực bãi biển Đồi Dương được thể hiện như Hình 1.

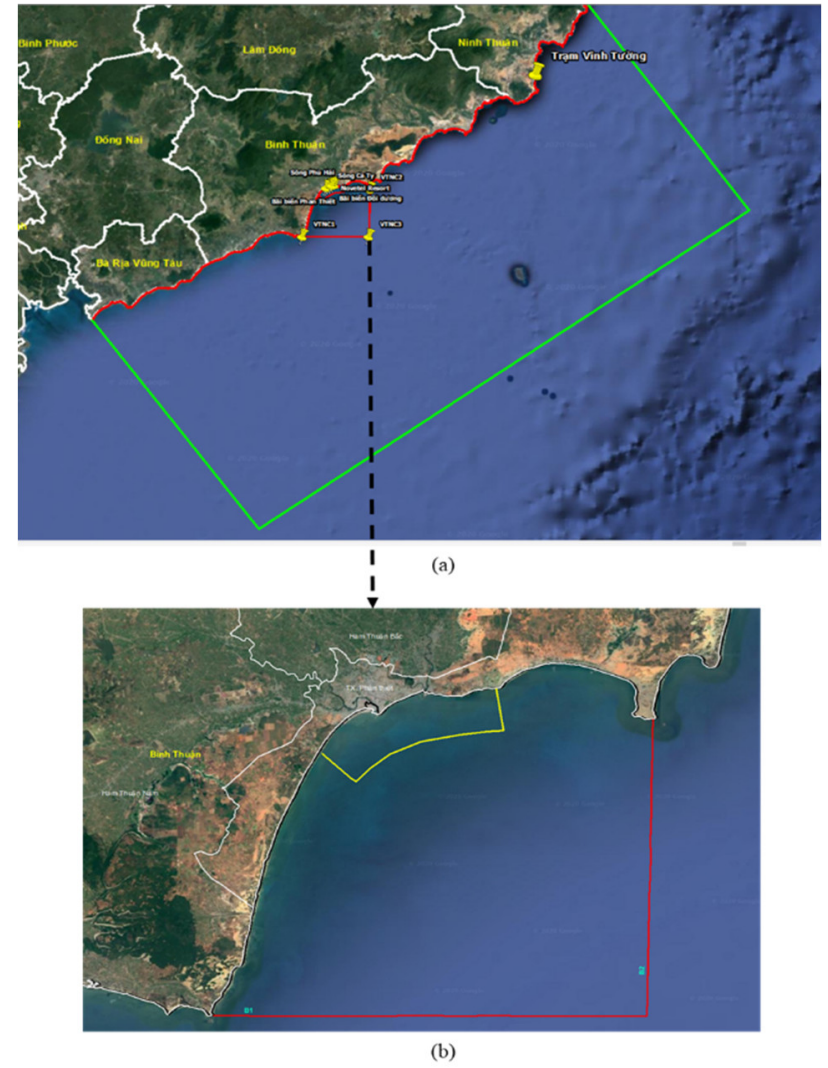

Hình 1. Phạm vi nghiên cứu (a); Toàn bộ vịnh Phan thiết và khu vực bãi biển Đồi Dương được giới hạn bởi đường màu vàng $(\mathrm{b})$. 


\section{Phương pháp nghiên cứu}

\subsection{Dũ liệu tính toán}

\subsubsection{Vùng tính và lưới tính}

Để giảm thiểu sai số khi mô phỏng tính toán từ các biên mở cho khu vực nghiên cứu, theo đó, vùng tính được mở rộng bao gồm: từ vị trí bãi Vọng Nguyệt (Bà Rịa-Vũng Tàu) đến vùng ven biển tỉnh Bình Thuận và Ninh Thuận với chiều dài bờ biển là $330 \mathrm{~km}$ và khoảng cách từ bờ ra ngoài khơi là 130 km. Phạm vi không gian miền tính trên Hình 2.

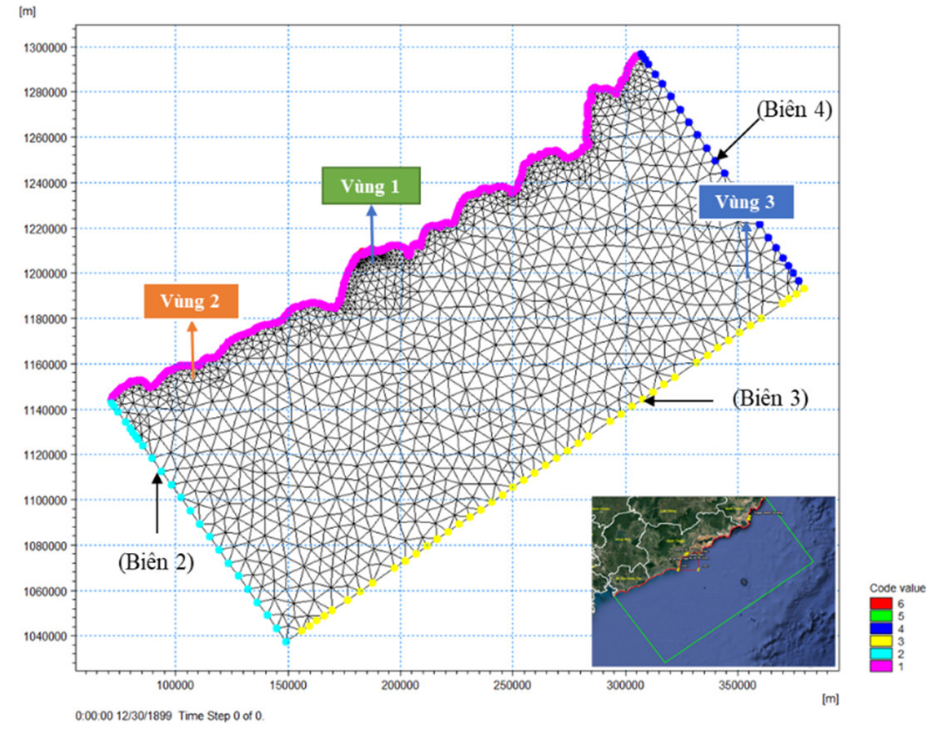

Hình 2. Vùng tính và lưới tính.

Lưới tính được thiết lập bằng công cụ Mesh Generator trong MIKE ZERO. Để mô phỏng tương đối chính xác địa hình đáy vùng ven biển, lựa chọn lưới phi cấu trúc phù hợp với địa hình đường bờ phức tạp, bao gồm 3850 ô lưới tính toán với 2246 nút lưới, diện tích ô lưới nhỏ nhất $168 \mathrm{~m}^{2}$. Lưới tính chia thành 3 vùng có diện tích: Khu vực bãi biển Đồi Dương $500000 \mathrm{~m}^{2}$ (Vùng 1), dọc đường bờ $3000000 \mathrm{~m}^{2}$ (Vùng 2) và ngoài biển khơi $32000000 \mathrm{~m}^{2}$ (Vùng 3).

\subsubsection{Dữ liệu đường bờ và địa hình đáy}

Đối với đường bờ, số liệu được thiết lập vào năm 2017 trên phần mềm Google Earth và được số hóa bằng phần mềm ARCGIS. Đối với địa hình đáy được thu thập từ:

+ Số liệu địa hình khu vực biển đông thu thập năm 2013, 2017: kế thừa từ kết quả nghiên cứu của Lê Đình Mầu và cộng sự "Đặc điểm khí tượng hải văn và động lực biển tỉnh Khánh Hoà" được thực hiện từ 2016-2018.

+ Dữ liệu địa hình vùng biển Bình Thuận thu thập năm 2013 và 2017, được cung cấp bởi Phòng vật lý biển, viện Hải Dương Học.

+ Số liệu địa hình chi tiết khu vực bãi biển Đồi Dương được đo năm 2020: kế thừa từ số liệu đo đạc từ đề tài "Nghiên cứu tính toán sự xuất hiện dòng Rip vùng ven biển Nam Trung Bộ, áp dụng cho bãi biển Đồi Dương tỉnh Bình Thuận".

\subsubsection{Dữ liệu cho mô hình tính toán sóng và dòng chảy}

Số liệu gió toàn cầu có độ phân giải 0,5 độ kinh vĩ, bước thời gian đo 3 tiếng (năm 2013 và 2017) thu thập từ Cơ quan Quản lý Khí quyển Đại dương Quốc gia Mỹ (NOAA). 
Số liệu sóng, dòng chảy năm 2013 phục vụ hiệu chỉnh và kiểm định: Số liệu sóng và dòng chảy thực đo tại trạm Vĩnh Trường thu thập của Công ty Tư vấn Xây dựng điện 2, Tập đoàn Điện lực Việt Nam (EVN).

\subsection{Co sở lý thuyết mô đun Mike $21 \mathrm{SW}$}

MIKE $21 \mathrm{SW}$ [11] là mô đun tính phổ sóng được tính toán dựa trên lưới phi cấu trúc. Mô đun này tính toán sự phát triển, suy giảm và truyền sóng tạo ra bởi gió và sóng lừng ở ngoài khơi và khu vực ven bờ.

Trong MIKE $21 \mathrm{SW}$, sóng gió được biểu diễn thông qua đại lượng phổ mật độ tác động $\mathrm{N}(\sigma, \theta)$.

Mật độ tác động $\mathrm{N}(\sigma, \theta)$ quan hệ với mật độ năng lượng $\mathrm{E}(\sigma, \theta)$ theo biểu thức:

$$
\mathrm{N}=\frac{\mathrm{E}}{\sigma}
$$

Đối với sóng lan truyền trên độ sâu và dòng chảy biến đổi nhỏ thì quan hệ giữa tần số góc tương đối và tần số góc tuyệt đối $\omega$ được xác định theo biểu thức tán xạ tuyến tính sau:

$$
\sigma=\sqrt{\mathrm{gk} \tanh (\mathrm{kd})}=\omega-\overrightarrow{\mathrm{k}} \cdot \overrightarrow{\mathrm{U}}
$$

Trong đó $\mathrm{g}\left(\mathrm{m} / \mathrm{s}^{2}\right)$ là gia tốc trọng trường; $\mathrm{d}(\mathrm{m})$ là độ sâu nước; $\overrightarrow{\mathrm{U}}$ là véc tơ vận tốc dòng chảy và $\mathrm{k}$ là số sóng có độ lớn $\mathrm{k}$ và hướng $\theta$.

Phương trình chủ đạo trong MIKE $21 \mathrm{SW}$ là phương trình cân bằng tác động của sóng trong toạ độ Đề Các hoặc là toạ độ cầu. Trong toạ độ Đề Các:

$$
\frac{\partial \mathrm{N}}{\partial \mathrm{t}}+\nabla \cdot(\overrightarrow{\mathrm{v}} \cdot \mathrm{N})=\frac{\mathrm{s}}{\sigma}
$$

Trong đó $\mathrm{N}(\overrightarrow{\mathrm{x}}, \sigma, \theta, \mathrm{t})$ là mật độ tác động; $\overrightarrow{\mathrm{x}}(\mathrm{x}, \mathrm{y})$ là toạ độ Đề Các; $\sigma$ là tần số góc tương đối $(\sigma=2 \pi \mathrm{f}) ; \theta$ (độ) là hướng sóng; $\mathrm{t}(\mathrm{s})$ là thời gian; $\nabla$ là toán tử đạo hàm riêng trong không gian $(\overline{\mathrm{x}}, \sigma, \theta), \overrightarrow{\mathrm{v}}\left(\mathrm{c}_{\mathrm{x}}, \mathrm{c}_{\mathrm{y}}, \mathrm{c}_{\delta}, \mathrm{c}_{\theta}\right)$ là tốc độ lan truyền của nhóm sóng trong không gian 4 chiều và $\mathrm{S}$ là số hạng nguồn trong phương trình cân bằng năng lượng.

$$
\mathrm{S}=\mathrm{S}_{\mathrm{in}}+\mathrm{S}_{\mathrm{nl}}+\mathrm{S}_{\mathrm{ds}}+\mathrm{S}_{\mathrm{bot}}+\mathrm{S}_{\text {Surf }}
$$

Trong đó $S_{\text {in }}$ là sự chuyển tải động lượng năng lượng gió vào sự phát sinh ra sóng; $S_{n l}$ là năng lượng chuyển tải do tương tác phi tuyến sóng-sóng; $S_{\mathrm{ds}}$ là sự tiêu tán năng lượng sóng do sóng bạc đầu; $\mathrm{S}_{\text {bot }}$ là sự tiêu tán do ma sát đáy; $\mathrm{S}_{\text {Surf }}$ là sự tiêu tán năng lượng do sự vỡ sóng do độ sâu.

Hàm mặc định của số hạng nguồn $\mathrm{S}_{\mathrm{in}}, \mathrm{S}_{\mathrm{nl}}$ và $\mathrm{S}_{\mathrm{ds}}$ trong MIKE $21 \mathrm{SW}$ tương tự như hàm nguồn trong mô hình WAM Cycle 4 [12].

\subsection{Co sở lý thuyết mô đun MIKE 21 FM HD}

Mô đun MIKE 21 FM HD [13] mô phỏng sự biến thiên lưu lượng và mực nước dựa trên phương trình liên tục và phương trình động lượng theo hai hướng:

Phương trình liên tục:

$$
\frac{\partial \mathrm{h}}{\partial \mathrm{t}}+\frac{\partial \mathrm{h} \overline{\mathrm{u}}}{\partial \mathrm{x}}+\frac{\partial \mathrm{h} \overline{\mathrm{v}}}{\partial \mathrm{y}}=\mathrm{hS}
$$

Phương trình động lượng theo phương $\mathrm{x}$ và $\mathrm{y}$ tương ứng:

+ Theo phương $\mathrm{x}$ :

$$
\begin{aligned}
\frac{\partial \mathrm{h} \overline{\mathrm{u}}}{\partial \mathrm{t}}+\frac{\partial \mathrm{hu}^{2}}{\partial \mathrm{x}}+ & \frac{\partial \mathrm{h} \overline{\mathrm{vu}}}{\partial \mathrm{y}} \\
& =\mathrm{f} \overline{\mathrm{v}}-\mathrm{gh} \frac{\partial \eta}{\partial \mathrm{x}}-\frac{\mathrm{h}}{\rho_{0}} \frac{\partial \mathrm{p}_{\mathrm{a}}}{\partial \mathrm{x}}-\frac{\mathrm{gh}^{2}}{2 \rho_{0}} \frac{\partial \rho}{\partial \mathrm{x}}+\frac{\tau_{\mathrm{sx}}}{\rho_{0}}-\frac{\tau_{\mathrm{bx}}}{\rho_{0}}-\frac{1}{\rho_{0}}\left(\frac{\partial \mathrm{S}_{\mathrm{xx}}}{\partial \mathrm{x}}+\frac{\partial \mathrm{S}_{\mathrm{xy}}}{\partial \mathrm{y}}\right) \\
& +\frac{\partial}{\partial \mathrm{x}}\left(\mathrm{hT}_{\mathrm{xx}}\right)+\frac{\partial}{\partial \mathrm{y}}\left(\mathrm{hT}_{\mathrm{xy}}\right)+\mathrm{hu}_{\mathrm{s}} S
\end{aligned}
$$


+ Theo phương y:

$$
\begin{aligned}
\frac{\partial \mathrm{h} \overline{\mathrm{v}}}{\partial \mathrm{t}}+\frac{\partial \mathrm{h} \overline{\mathrm{uv}}}{\partial \mathrm{x}}+ & \frac{\partial \mathrm{h} \bar{v}^{2}}{\partial \mathrm{y}} \\
& =-\mathrm{fu} \mathrm{h}-\mathrm{gh} \frac{\partial \eta}{\partial \mathrm{y}}-\frac{\mathrm{h}}{\rho_{0}} \frac{\partial \mathrm{p}_{\mathrm{a}}}{\partial \mathrm{y}}-\frac{\mathrm{gh}^{2}}{2 \rho_{0}} \frac{\partial \rho}{\partial \mathrm{y}}+\frac{\tau_{\mathrm{sy}}}{\rho_{0}}-\frac{\tau_{\mathrm{by}}}{\rho_{0}} \\
& -\frac{1}{\rho_{0}}\left(\frac{\partial \mathrm{S}_{\mathrm{yx}}}{\partial \mathrm{x}}+\frac{\partial \mathrm{S}_{\mathrm{yy}}}{\partial \mathrm{y}}\right)+\frac{\partial}{\partial \mathrm{x}}\left(\mathrm{hT}_{\mathrm{xy}}\right)+\frac{\partial}{\partial \mathrm{y}}\left(\mathrm{hT}_{\mathrm{yy}}\right)+\mathrm{hv}_{\mathrm{s}} \mathrm{S}
\end{aligned}
$$

Trong đó $\mathrm{t}$ là thời gian $(\mathrm{s}) ; \mathrm{x}, \mathrm{y}$ là toạ độ Đề Các $(\mathrm{m}) ; \eta$ là dao động mực nước $(\mathrm{m}) ; \mathrm{d}$ là độ sâu của mực nước; $\mathrm{h}$ là tổng độ sâu mực nước $(\mathrm{m}) ; \mathrm{g}$ là gia tốc trọng trường $\left(\mathrm{m} / \mathrm{s}^{2}\right) ; \mathrm{f}=$ $2 \Omega \sin \phi$ : tham số Coriolis $\left(\mathrm{s}^{-1}\right) ; \rho_{0}$ là khối lượng riêng của nước $\left(\mathrm{kg} / \mathrm{m}^{3}\right) ; \mathrm{p}_{\mathrm{a}}$ là áp suất khí quyển $(\mathrm{Pa} / \mathrm{m}) ; \mathrm{S}$ là lưu lượng nguồn $\left(\mathrm{m}^{3} / \mathrm{s}\right) ; \mathrm{u}_{\mathrm{s}}, \mathrm{v}_{\mathrm{s}}$ là vận tốc của nước đi vào miền tính theo phương $\mathrm{x}$ và phương $\mathrm{y}(\mathrm{m} / \mathrm{s}) ; \overline{\mathrm{u}}, \overline{\mathrm{v}}$ là vận tốc trung bình theo độ sâu $(\mathrm{m} / \mathrm{s}) ; T x x, T x y$, Tyy là các thành phần nội ứng suất, được xác định theo công thức độ nhớt xoáy dựa trên vận tốc trung bình theo độ sâu; $\tau_{\mathrm{sx}}, \tau_{\mathrm{sy}}$ là ứng suất ma sát bề mặt theo phương $\mathrm{x}$ và $\mathrm{y}\left(\mathrm{N} / \mathrm{m}^{2}\right)$; $\tau_{\mathrm{bx}}, \tau_{\mathrm{by}}$ là ứng suất ma sát đáy theo phương $\mathrm{x}$ và $\mathrm{y}\left(\mathrm{N} / \mathrm{m}^{2}\right)$; $\mathrm{A}$ là hệ số nhớt rối theo phương ngang $\left(\mathrm{m}^{2} / \mathrm{s}\right) ; \mathrm{S}_{\mathrm{xx}}, \mathrm{S}_{\mathrm{xy}}, \mathrm{S}_{\mathrm{yx}}, \mathrm{S}_{\mathrm{yy}}$ là các thành phần của ứng suất tán xạ sóng lên đơn vị thể tích nước theo các phương $\mathrm{x}$ và $\mathrm{y}\left(\mathrm{N} / \mathrm{m}^{2}\right)$. Úng suất tán xạ sóng được tính theo công thức:

$$
\begin{gathered}
S_{x x}=E\left(\left(\frac{k h}{\sinh 2 k h}+\frac{1}{2}\right) \cos ^{2} \theta+\frac{k h}{\sinh 2 k h}\right) \\
S_{y y}=E\left(\left(\frac{k h}{\sinh 2 k h}+\frac{1}{2}\right) \sin ^{2} \theta+\frac{k h}{\sinh 2 k h}\right) \\
S_{x y}=S_{y x}=E\left(\left(\frac{k h}{\sinh 2 k h}+\frac{1}{2}\right) \sin \theta \cos \theta\right)
\end{gathered}
$$

Trong đó $\theta$ là góc sóng tới; $\mathrm{E}$ là năng lượng sóng; $\mathrm{k}$ là số sóng.

\subsection{Thiết lập mô hình}

Bài báo áp dụng MIKE 21 với hai mô đun, cụ thể là mô đun sóng (SW) và mô đun thủy động lực học (HD), tác giả thực hiện các bước tính toán chính như trình bày trong khung phương pháp luận ở Hình 3.

\subsubsection{Mô hình tính sóng (MIKE 21 SW)}

Thời gian tính: Từ $8 \mathrm{~h} 00$ ngày $07 / 01 / 2013$ đến $22 \mathrm{~h} 00$ ngày $11 / 01 / 2013$ cho quá trình hiệu chỉnh và $11: 12$ ngày $01 / 07 / 2013$ đến $23: 12$ ngày $07 / 07 / 2013$ cho quá trình kiểm định.

Bước thời gian: 3600 giây

Điều kiện ban đầu được thiết lập là không có sự biến thiên của mực nước và dòng chảy tại khu vực nghiên cứu. Hiểu cách khác là trường hợp của bài toán đặt điều kiện biên ban đầu cho khu vực nghiên cứu như một khối nước tĩnh, các dao động sóng hình thành từ nguồn dữ liệu gió toàn cầu trên toàn miền tính và không xét đến sự dao động của thủy triều.

Điều kiện biên bao gồm các biên Bắc, Đông, Nam đều được thiết lập là mực nước tĩnh (độ cao sóng $\mathrm{h}=0$ ).

Điều kiện gió: Số liệu gió toàn cầu của cơ quan Quản lý Khí quyển đại dương Quốc gia Mỹ (NOAA) với độ phân giải 0,5 độ kinh vĩ, bước thời gian đo 3 tiếng.

Thông số dùng để hiệu chỉnh là hệ số sóng vỡ, hệ số ma sát đáy, hệ số phân tán là $\mathrm{C}_{\text {dis }}$ và DELTA dis.

\subsubsection{Mô hình dòng chảy (MIKE 21 HD FM)}

Thời gian tính:

+ Thời gian hiệu chỉnh: Từ 7h00 ngày 01/07/2013 đến 23 h00 ngày 15/07/2013 
+ Thời gian kiểm định: 00h00 ngày 16/07/2013 đến 16h00 ngày 27/07/2013.

Điều kiện ban đầu: Mực nước $=0 \mathrm{~m}$, vận tốc trên toàn miền tính $=0 \mathrm{~m} / \mathrm{s}$.

Điều kiện biên:

+ Chuỗi giá trị mực nước $(Z)$ thay đổi theo thời gian và không gian, từ phân tích điều hòa (Tide Predictions of Heights) tích hợp sẵn trong MIKE 21; Sử dụng số liệu mực nước triều tính toán từ bộ hằng số điều hòa thủy triều toàn cầu [14] tại 3 biên lỏng ngoài khơi.

+ Điều kiện sóng: Kết quả $S_{x x}, S_{x y}, S_{y y}\left(\mathrm{~m}^{3} / \mathrm{s}^{2}\right)$ sau khi tính toán từ mô đun Mike 21 SW sẽ là đầu vào cho mô đun MIKE 21 FM HD để tính toán dòng chảy, và mô hình Mike 21 tính toán coupled.

Thông số dùng để hiệu chỉnh là hệ số Manning's M.

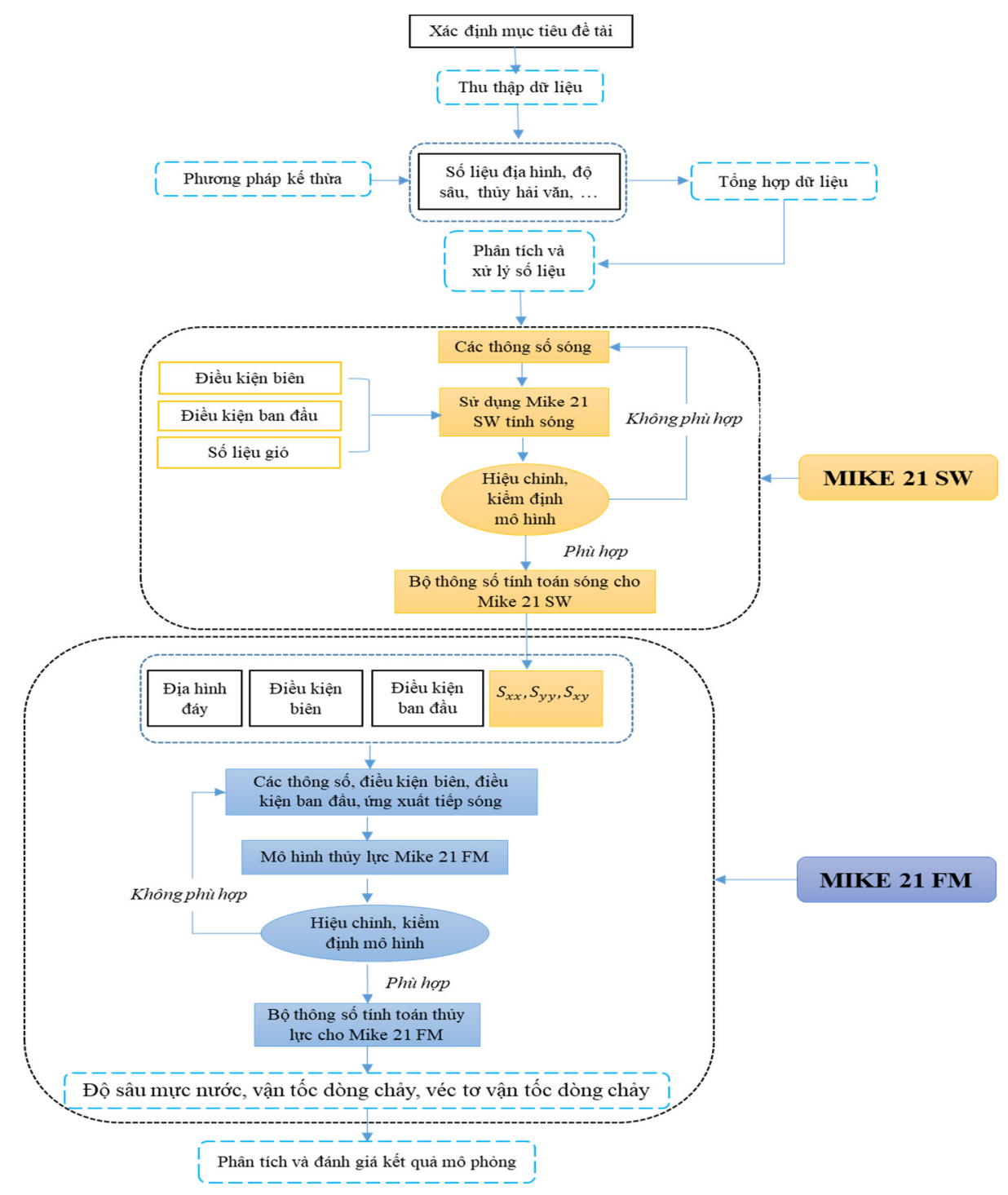

Hình 3. Khung định hướng nghiên cứu.

\section{Kết quả và thảo luận}

\subsection{Kết quả hiệu chỉnh và kiểm định mô hình sóng}

Nghiên cứu sử dụng chuỗi số liệu thực đo sóng tại trạm Vĩnh Trường $\left(11^{\circ} 26^{\prime} 13.00^{\prime} \mathrm{N}, 109^{\circ} 1^{\prime} 9.98^{\prime \prime} \mathrm{E}\right)$ trong thời gian từ 8 h00 ngày $07 / 01 / 2013$ đến $22 \mathrm{~h} 00$ ngày $11 / 01 / 2013$ để hiệu chỉnh mô hình và từ $11: 12$ ngày $01 / 07 / 2013$ đến $23: 12$ ngày $07 / 07 / 2013$ để kiểm định mô hình. Kết quả hiệu chỉnh và kiểm định mô hình sóng được trình bày trên Hình 4 và Hình 5. 


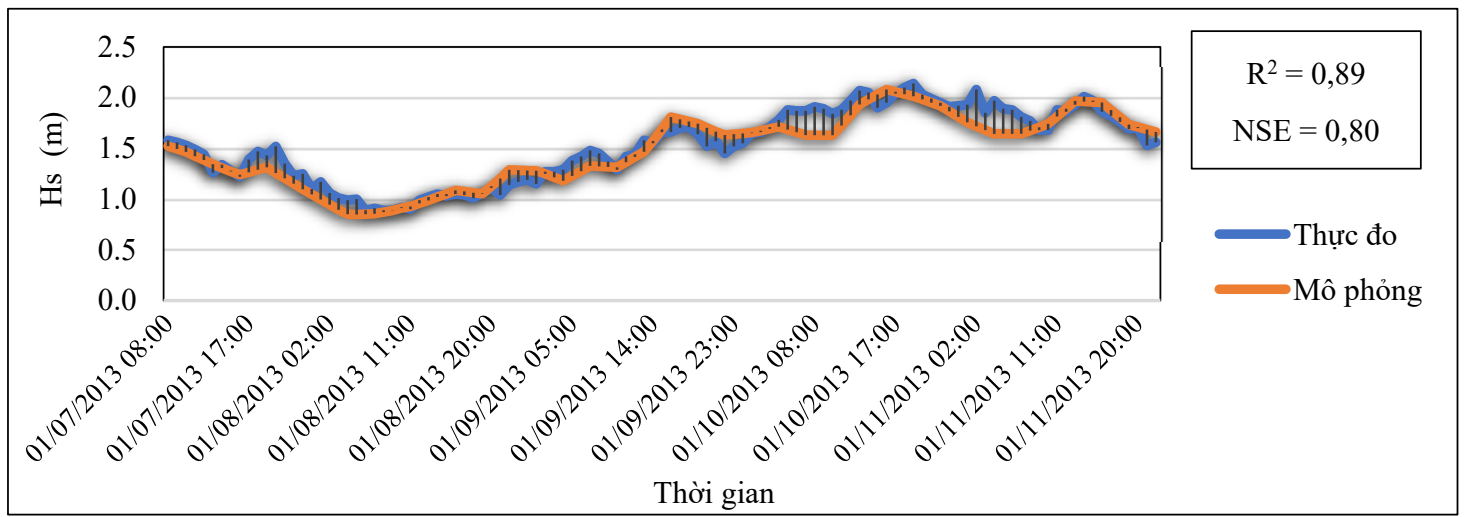

Hình 4. Đồ thị so sánh độ cao sóng có nghĩa $(\mathrm{Hs})$ thực đo và tính toán tại trạm hiệu chỉnh từ $8 \mathrm{~h} 00$ ngày $07 / 01 / 2013$ đến $22 \mathrm{~h} 00$ ngày $11 / 01 / 2013$.

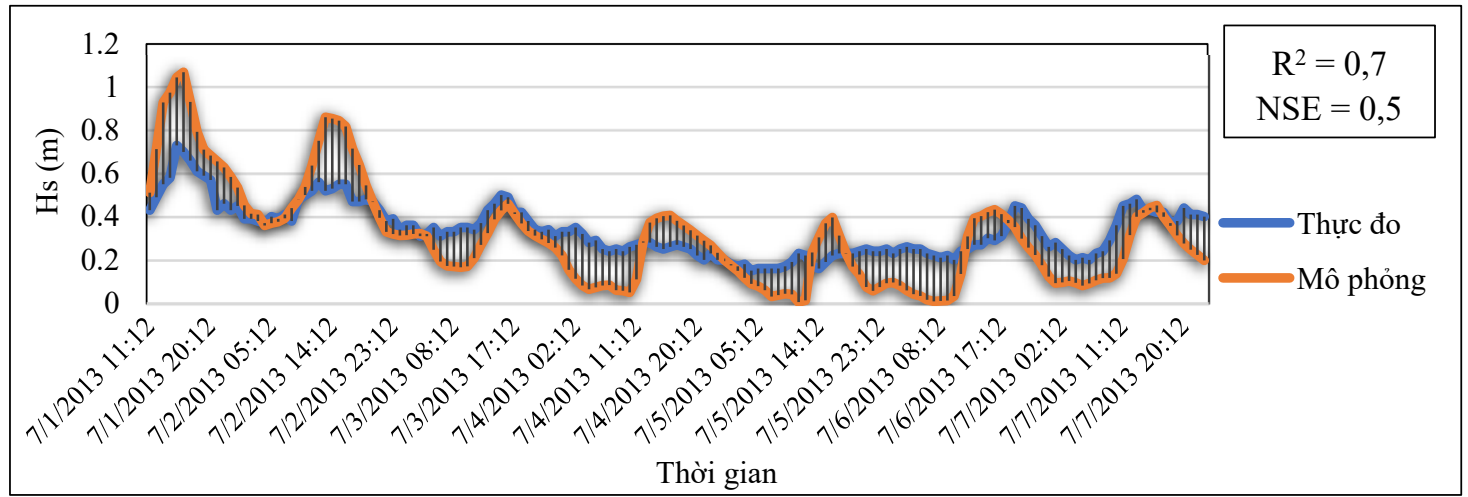

Hình 5. Đồ thị so sánh độ cao sóng có nghĩa (Hs) thực đo và tính toán từ 11:12 ngày 01/07/2013 đến 23:12 ngày $07 / 07 / 2013$.

Hiệu chỉnh (Hình 4) và kiểm định (Hình 5) mô hình cho thấy kết quả tính toán tương đối phù hợp với kết quả thực đo, chỉ số $\mathrm{NSE}$ và $\mathrm{R}^{2}$ giữa kết quả đo đạc và tính toán đạt ở mức khá tốt [15], qua đó khẳng định kết quả mô phỏng đảm bảo độ tin cậy, có thể sử dụng bộ thông số của mô hình (Bảng 1) phục vụ tính toán các kịch bản tiếp theo.

Bảng 1. Bộ tham số hiệu chỉnh.

\begin{tabular}{lc}
\hline \multicolumn{1}{c}{ Tham số } & Giá trị, đơn vị \\
\hline Hệ số sóng vỡ & 0,8 \\
Hệ số ma sát đáy & $0,002(\mathrm{~m})$ \\
Hệ số phân tán là C dis & 3 \\
DELTA dis & 0,0125 \\
\hline
\end{tabular}

\subsection{Kết quả hiệu chỉnh và kiểm định mô hình dòng chảy}

Quá trình hiệu chỉnh dòng chảy được thực hiện bằng cách thay đổi hệ số Manning's $\mathrm{M}$ theo độ sâu địa hình. Kết quả tính toán dòng chảy được hiệu chỉnh và kiểm định với chuỗi số liệu thực đo tại trạm Vĩnh Trường.

Thời gian hiệu chỉnh: 7 h00 ngày $01 / 07 / 2013$ đến 23 h00 ngày $15 / 07 / 2013$.

Thời gian kiểm định: $00 \mathrm{~h} 00$ ngày $16 / 07 / 2013$ đến $16 \mathrm{~h} 00$ ngày $27 / 07 / 2013$.

Kết quả hiệu chỉnh và kiểm định dòng chảy được thể hiện như Hình 6 và Hình 7 . 


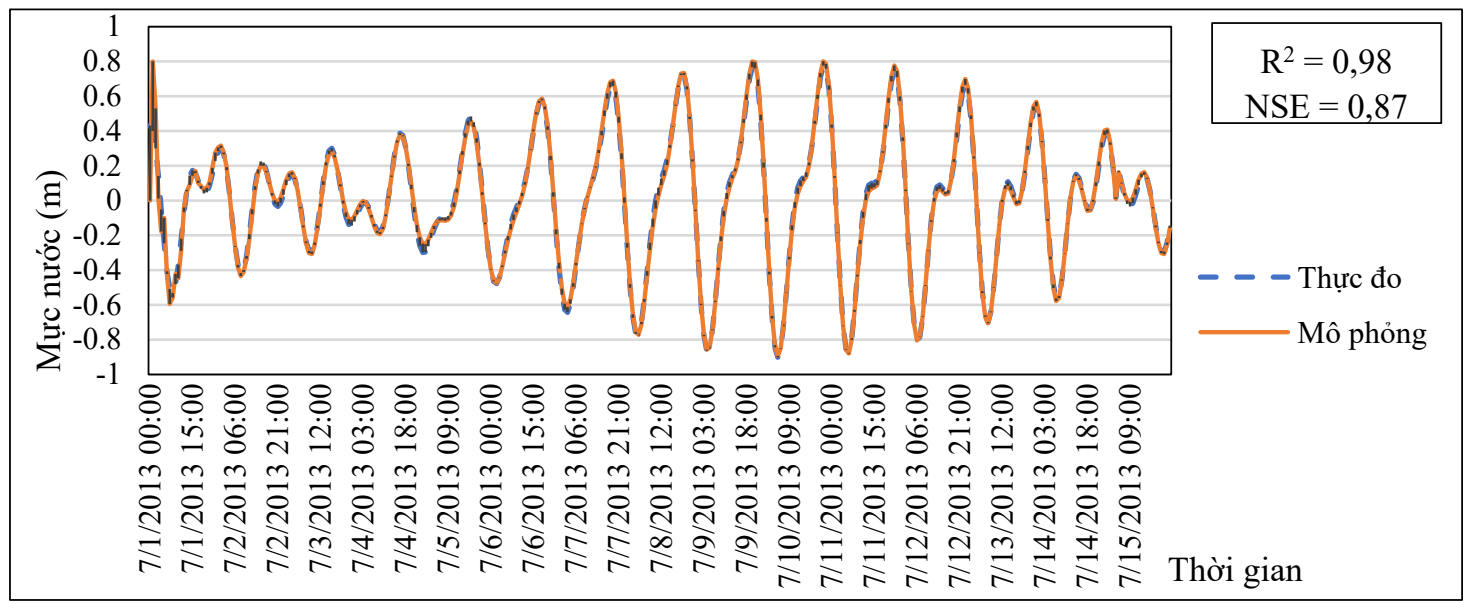

Hình 6. Đồ thị so sánh độ mực nước thực đo và tính toán tại trạm hiệu chỉnh từ 7h00 ngày 01/07/2013 đến 23 h00 ngày 15/07/2013.

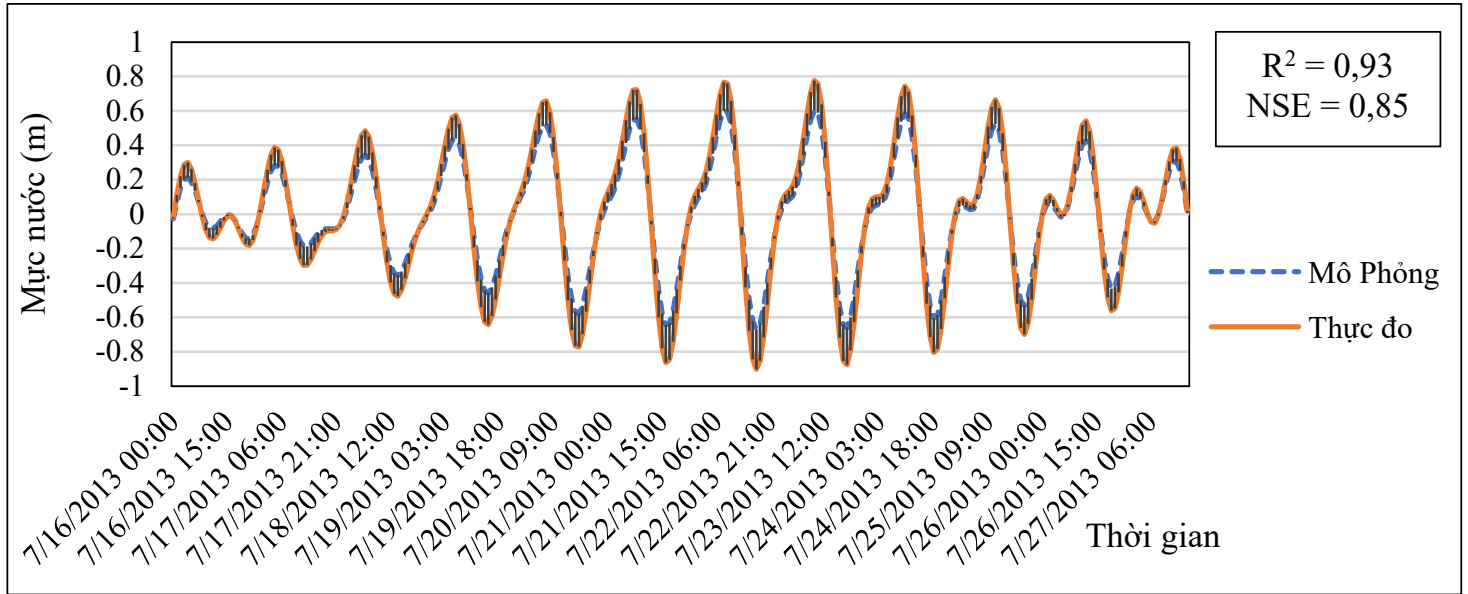

Hình 7. Đồ thị so sánh độ mực nước thực đo và tính toán tại trạm hiệu chỉnh từ 00 h00 ngày $16 / 07 / 2013$ đến 16 h00 ngày 27/07/2013.

Kết quả hiệu chỉnh $\left(\mathrm{NSE}=0,87\right.$ và $\left.\mathrm{R}^{2}=0,98\right)$ và kiểm định $\left(\mathrm{NSE}=0,85\right.$ và $\left.\mathrm{R}^{2}=0,93\right)$ cho thấy mức độ phù hợp giữa số liệu thực đo và tính toán đối với mực nước đạt loại tốt và hướng dòng chảy đạt loại khá.

\subsection{Kết quả mô phỏng sóng khu vục nghiên cứu}

Kết quả tính toán trường sóng trong tháng 1 cho thấy khu vực nghiên cứu khi chịu tác động chủ yếu bởi gió mùa Đông Bắc thì trường sóng ngoài khơi có hướng chủ yếu là hướng Đông Bắc, hướng của sóng biển khơi trùng với hướng gió. Khi vào đến cửa sông Phú Hải và Cà Ty hướng sóng bị tác động của hình thái cửa sông và khúc xạ do sự nông dần của địa hình nên có sự chuyển sang hướng Đông Đông Nam (Hình 8). Độ cao sóng vào tháng 1 từ $0,5-3$ $\mathrm{m}$, chu kỳ sóng khu vực cửa sông khoảng 3 giây.

Đến tháng 7, khu vực nghiên cứu chịu tác động trực tiếp của chế độ gió mùa Tây Nam, hướng sóng khoảng 225 độ, hướng Tây Nam chủ đạo, khi vào gần bờ thì chuyển sang hướng nam Tây Nam (Hình 9). 


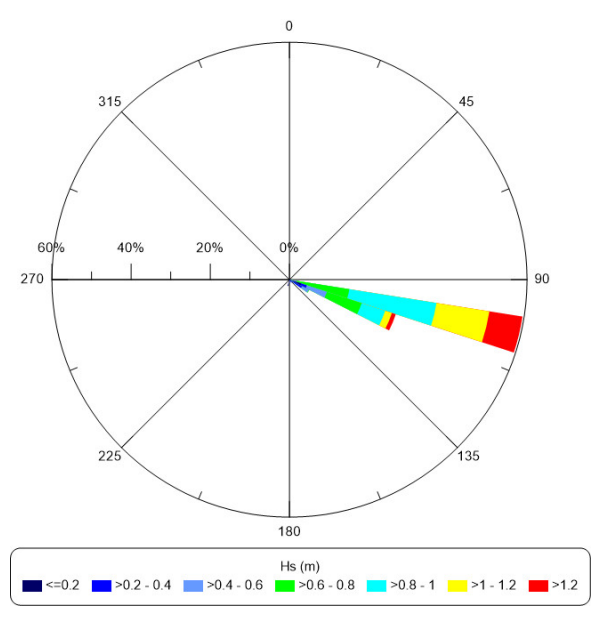

Hình 8. Biểu đồ Hoa sóng tháng 1 tại điểm có toạ độ (184513.500878, 1208397.703794).

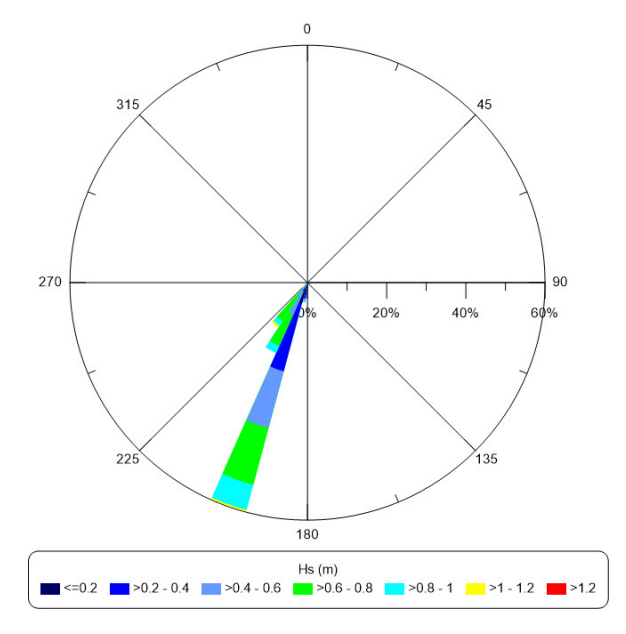

Hình 9. Biểu đồ Hoa sóng tháng 7 tại điểm có tọa độ (184513.500878, 1208397.703794).

\subsection{Kết quả mô phỏng dòng chảy}

Dòng chảy khu vực bãi biển Đồi Dương có đặc trưng của dòng chảy vịnh Phan Thiết, do đó, bài báo tiến hành phân tích chế độ dòng chảy tại khu vực Vịnh Phan Thiết và từ đó làm rõ chế độ dòng chảy tại bãi biển Đồi Dương.

\subsubsection{Mô phỏng dòng chảy trong trường hợp gió mùa Đông Bắc}

- Dòng chảy dưới ảnh hưởng của gió Đông Bắc:

Dưới ảnh hưởng của gió Đông Bắc (Hình 10), dòng chảy sinh ra do gió trong khu vực nghiên cứu có vận tốc dao động khoảng $0,04-0,44 \mathrm{~m} / \mathrm{s}$; vận tốc dòng chảy ở khu vực sát bờ nhỏ hơn vì chịu ảnh hưởng bởi địa hình và ma sát đáy lớn. Gió Đông Bắc ảnh hưởng rất ít trong khu vực cửa sông Cà Ty và Phú Hải (bãi biển Đồi Dương), vận tốc dòng chảy trong khu vực này nhỏ khoảng $0,008-0,096 \mathrm{~m} / \mathrm{s}$ vì đặc điểm địa hình khu vực này là nhỏ và hẹp, chính điều này làm giảm ảnh hưởng của gió lên dòng chảy.

- Dòng chảy dưới ảnh hưởng của sóng Đông Bắc:

Từ Hình 11 ta thấy vận tốc dòng chảy khu tại khu vực bãi biển Đồi Dương rất nhỏ, dao động khoảng $0,002-0,04 \mathrm{~m} / \mathrm{s}$, nên sóng truyền theo hướng Đông không ảnh hưởng nhiều lên khu vực này.

- Dòng chảy dưới ảnh hưởng của triều trong mùa gió Đông Bắc:

Khi không xét tới sự tác động của sóng và gió, kết quả dòng chảy triều được mô phỏng như Hình 12. Thời gian triều lên ngắn hơn thời gian triều xuống, vận tốc dòng trung bình trong toàn miền tính dao động trong khoảng $0,05-1,2 \mathrm{~m} / \mathrm{s}$. Tốc độ dòng chảy tại các vị trí gần cửa sông tại bãi biển Đồi Dương khi triều dâng và rút có giá trị gần như tương đương nhau (khoảng $<1 \mathrm{~m} / \mathrm{s}$ ).

- Dòng chảy tổng cộng (ảnh hưởng của triều, sóng Đông và gió Đông Bắc kết hợp).

Để xem xét rõ hơn về ảnh hưởng của các dòng chảy thành phần lên dòng chảy tổng hợp tại khu vực nghiên cứu. Bài báo đã tiến hành trích xuất đặc trưng dòng chảy vào 7 giờ ngày 22 tháng 1 năm 2017 tại khu vực quanh đảo Phú Quý (Hình 13) và khu vực ven bờ thuộc Vịnh Phan Thiết - bãi biển Đồi Dương (Hình 14).

Kết quả hình 13 cho thấy: Dòng chảy tại đây không bị ảnh hưởng nhiều bởi sóng Đông, vận tốc chỉ đạt khoảng $0-0,08 \mathrm{~m} / \mathrm{s}$. Phần lớn dòng chảy dịch chuyển từ hướng Tây Tây Nam lên hướng Đông Đông Bắc; Dòng chảy sinh ra do gió Đông Bắc có vận tốc dao động khoảng $0,15-0,29 \mathrm{~m} / \mathrm{s}$. Dòng chảy dịch chuyển từ hướng Đông Bắc về hướng Tây Nam là chủ yếu; 
Dưới ảnh hưởng của Triều, vận tốc dòng chảy tại đây đạt khoảng $0,26-0,33 \mathrm{~m} / \mathrm{s}$. Dòng chảy dịch chuyển theo nhiều hướng nhưng chủ yếu chảy từ hướng Đông Bắc về hướng Tây Nam.

Khi tiến vào gần bờ, dòng chảy tại khu vực này chảy theo 2 hướng chính là Tây Bắc và Đông Nam. Dòng chảy biến động theo pha dao động của mực nước với hai hướng chủ đạo: trong pha triều lên dòng chảy có hướng chủ đạo là từ phía ngoài biển vào trong các cửa sông; ngược lại trong pha triều xuống.

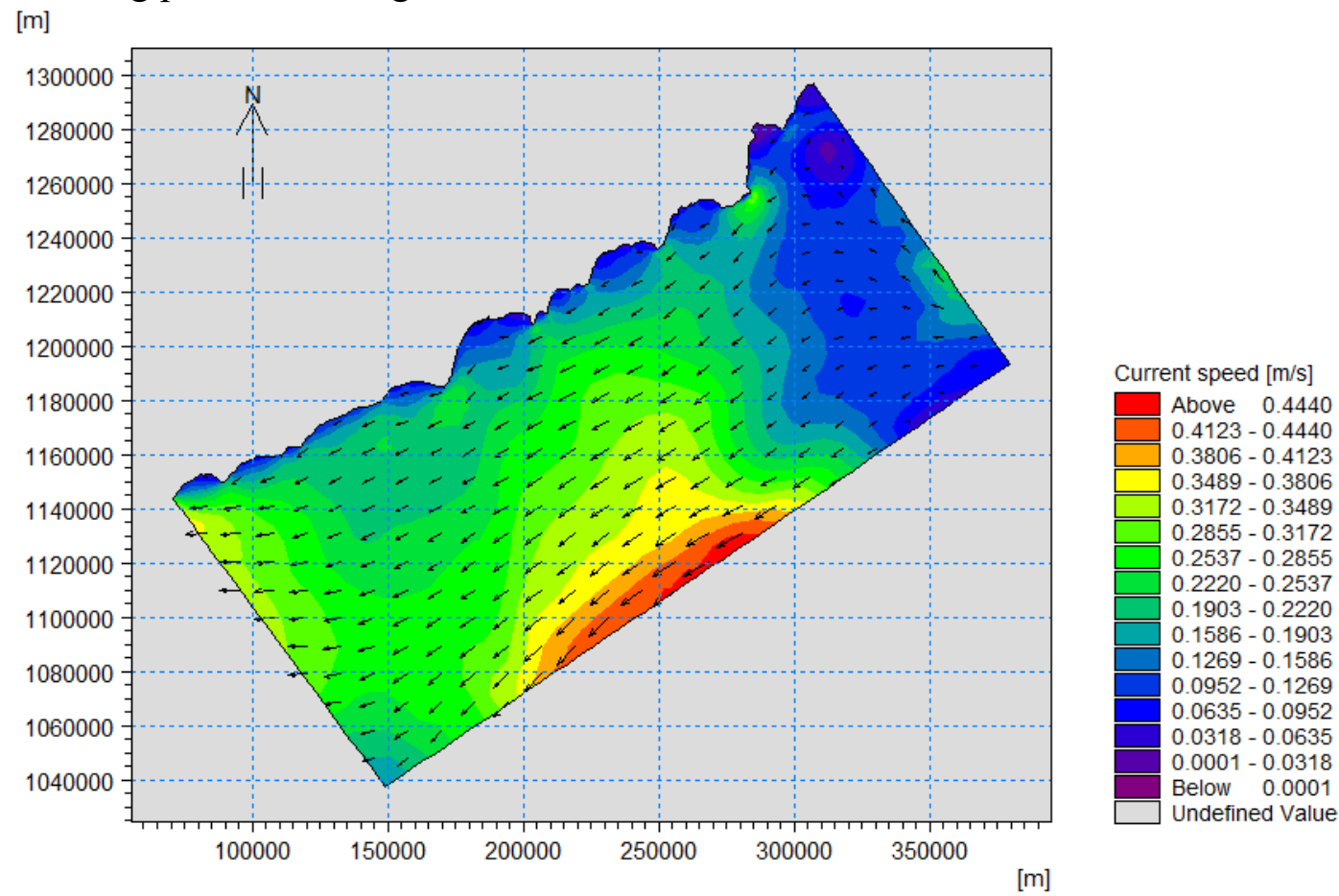

21:00:00 1/15/2017 Time Step 350 of 672

Hình 10. Trường vận tốc dòng chảy dưới ảnh hưởng của gió Đông Bắc.

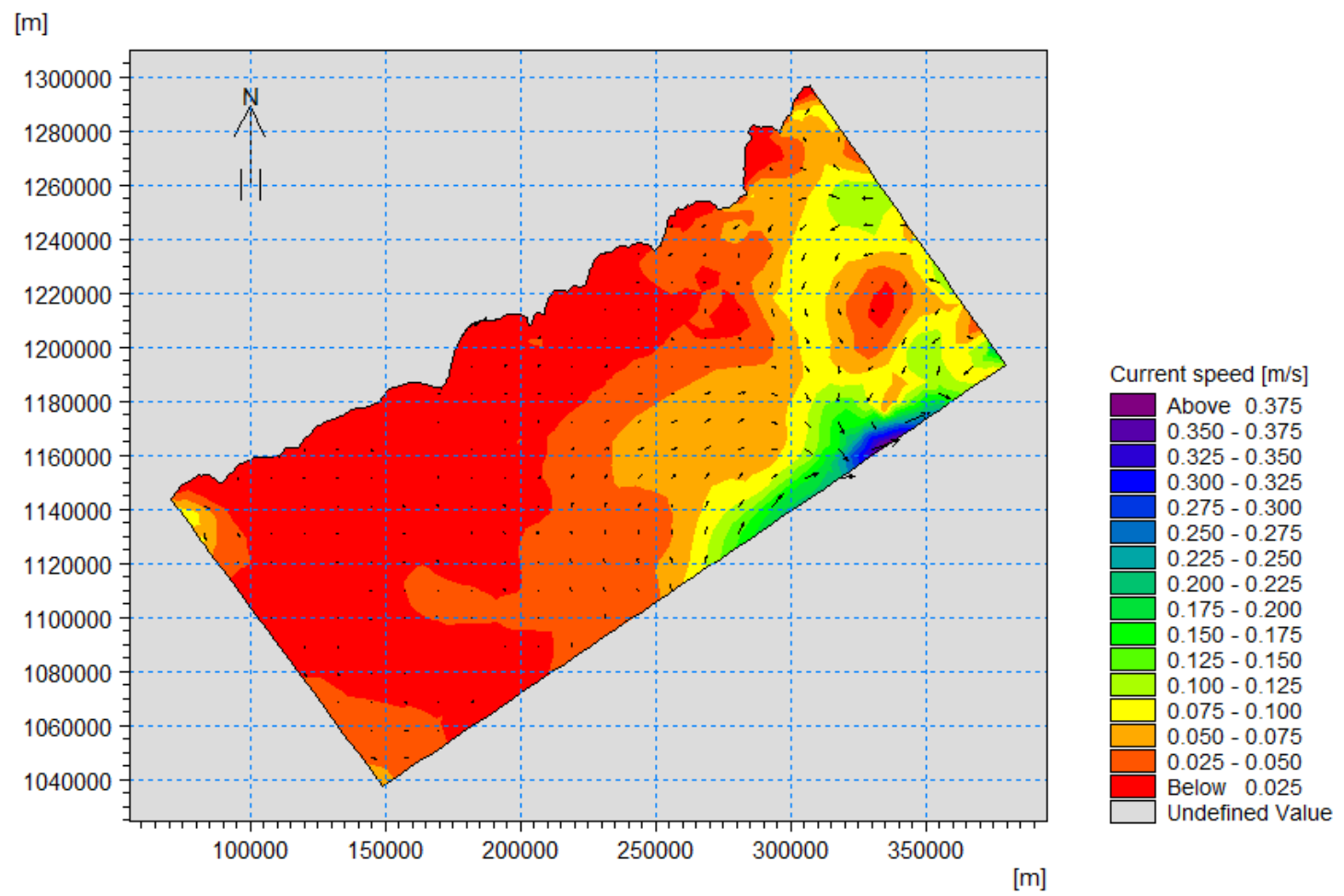

19:00:00 1/13/2017 Time Step 300 of 672.

Hình 11. Trường vận tốc dòng chảy dưới ảnh hưởng của sóng vào mùa Đông Bắc. 
$[\mathrm{m}]$

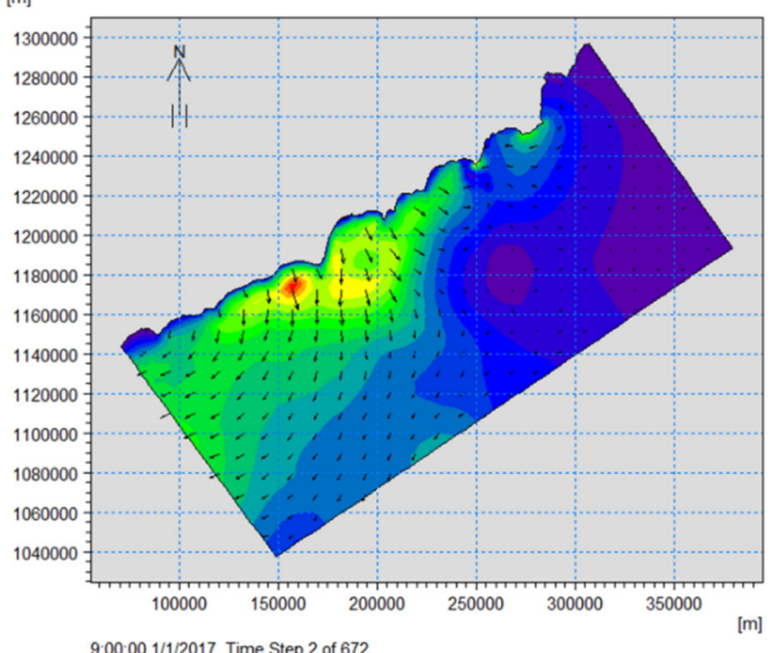

(a)

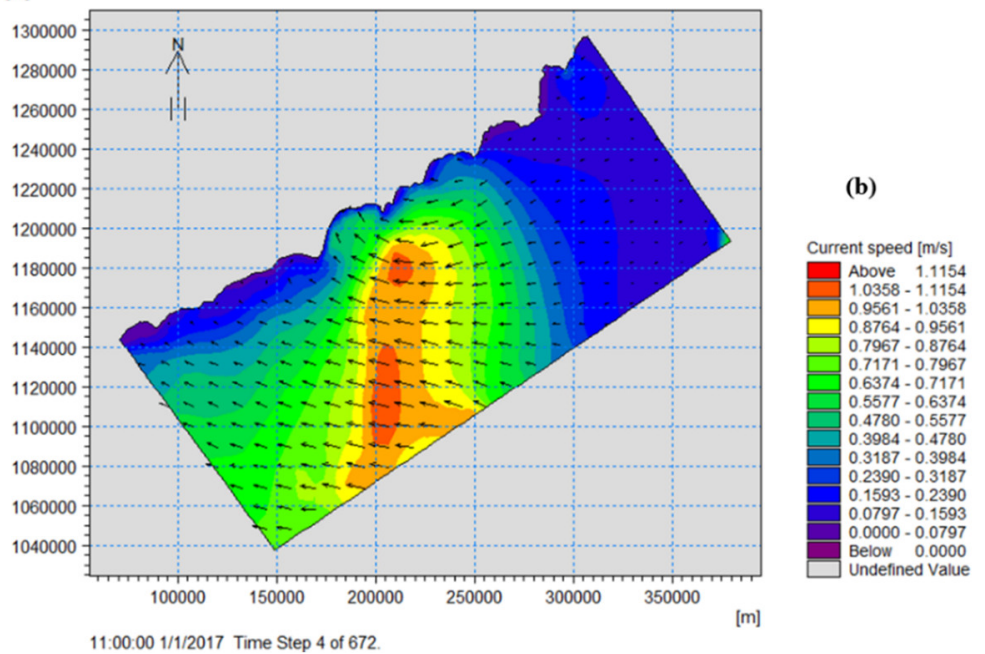

Hình 12. Trường vận tốc dòng chảy lúc triều xuống (a) và triều lên (b).

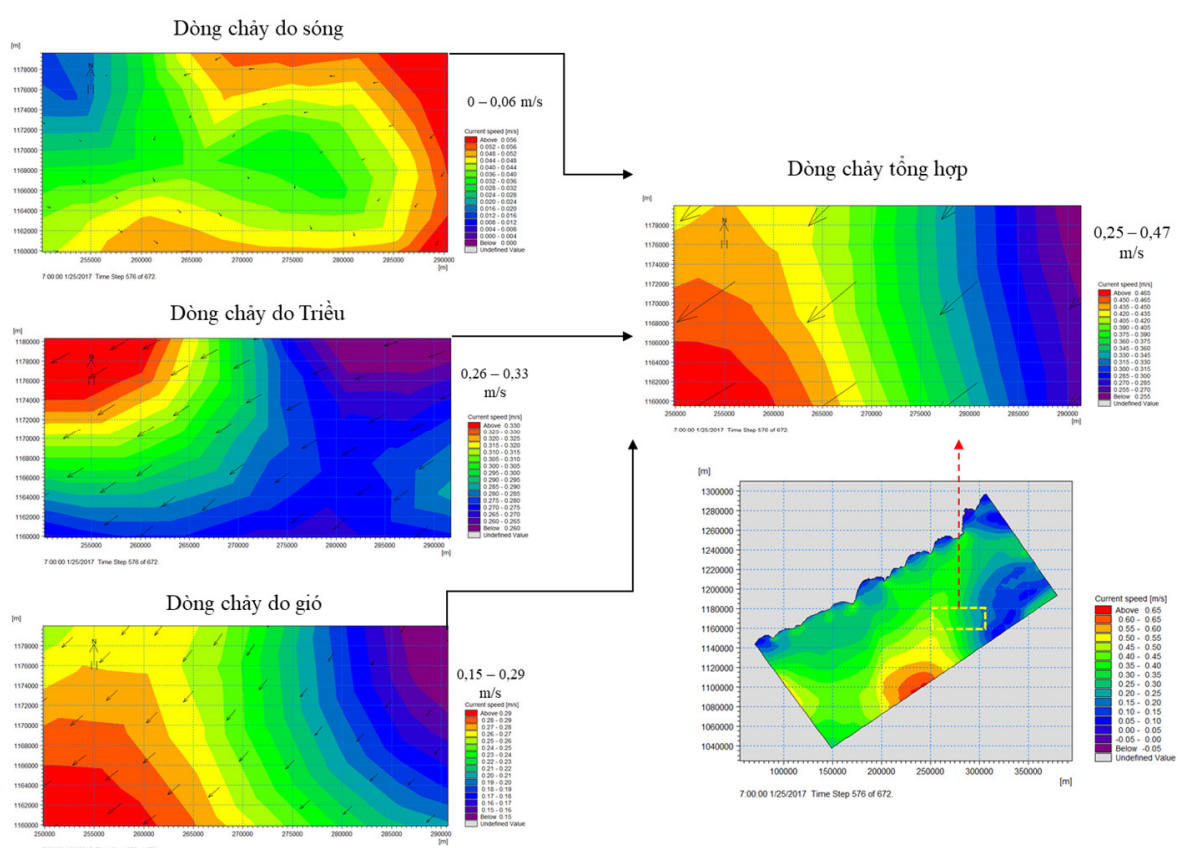

Hình 13. Ảnh hưởng của dòng chảy thành phần tại khu vực ngoài khơi vào gió mùa Đông Bắc. 


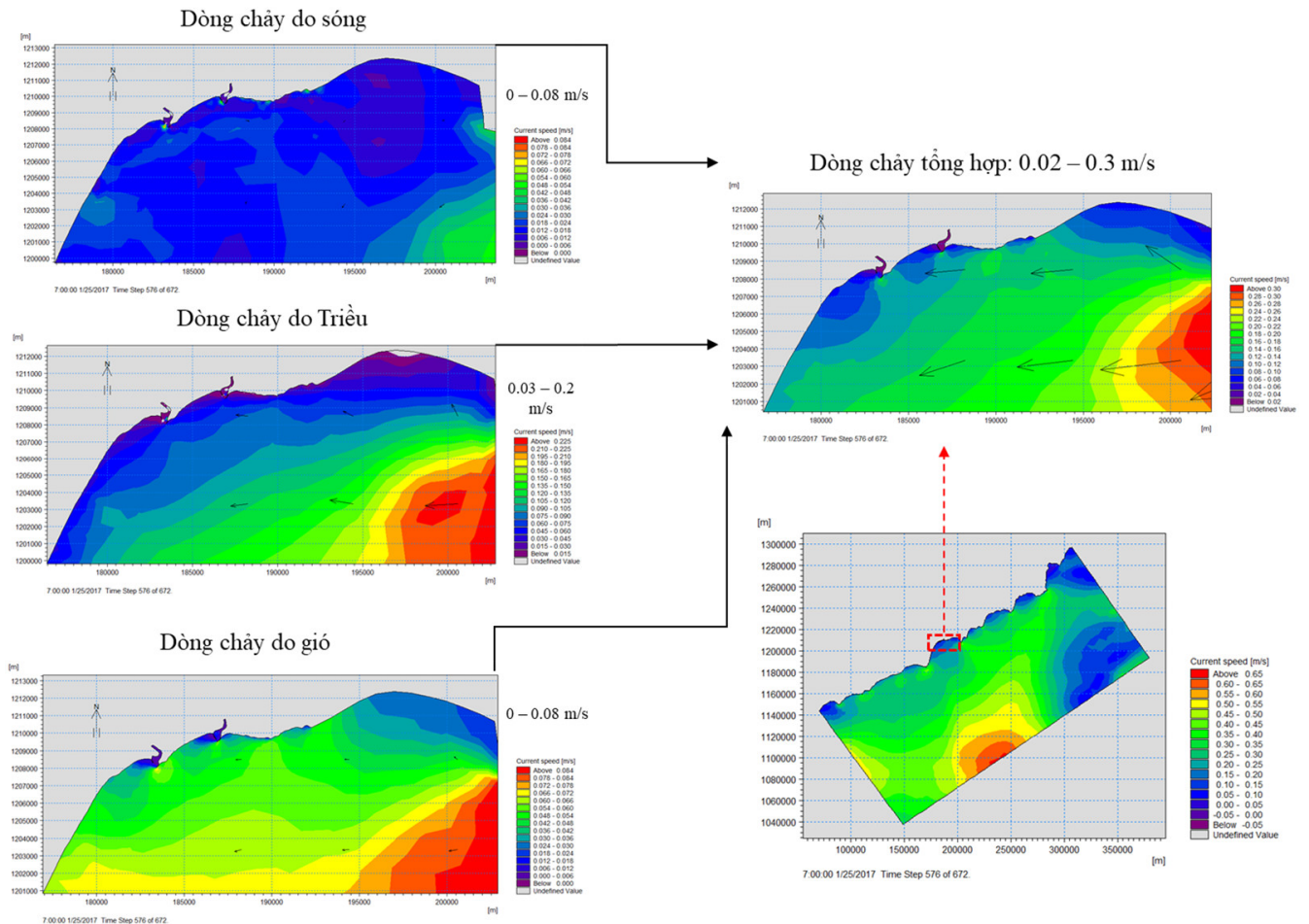

Hình 14. Ảnh hưởng của dòng chảy thành phần tại khu vực ven bờ vào gió mùa Đông Bắc.

Theo phân tích cho thấy, chế độ dòng chảy khu vực vịnh Phan Thiết nói chung và bãi biển Đồi Dương nói riêng chịu ảnh hưởng mạnh bởi dòng triều, ảnh hưởng do sóng và ảnh hưởng của gió lên dòng chảy là ít hơn.

\subsubsection{Mô phỏng dòng chảy trong trường hợp gió mùa Tây Nam}

- Dòng chảy dưới ảnh hưởng của gió Tây Nam: Dưới ảnh hưởng của gió Tây Nam, dòng chảy sinh ra do gió trong khu vực nghiên cứu có vận tốc dao động khoảng $0,08-0,6 \mathrm{~m} / \mathrm{s}$ (Hình 15), khi vào đến bãi biển Đồi Dương, vận tốc dòng chảy nhỏ dần, chỉ đạt khoảng 0,04 $\mathrm{m} / \mathrm{s}$.

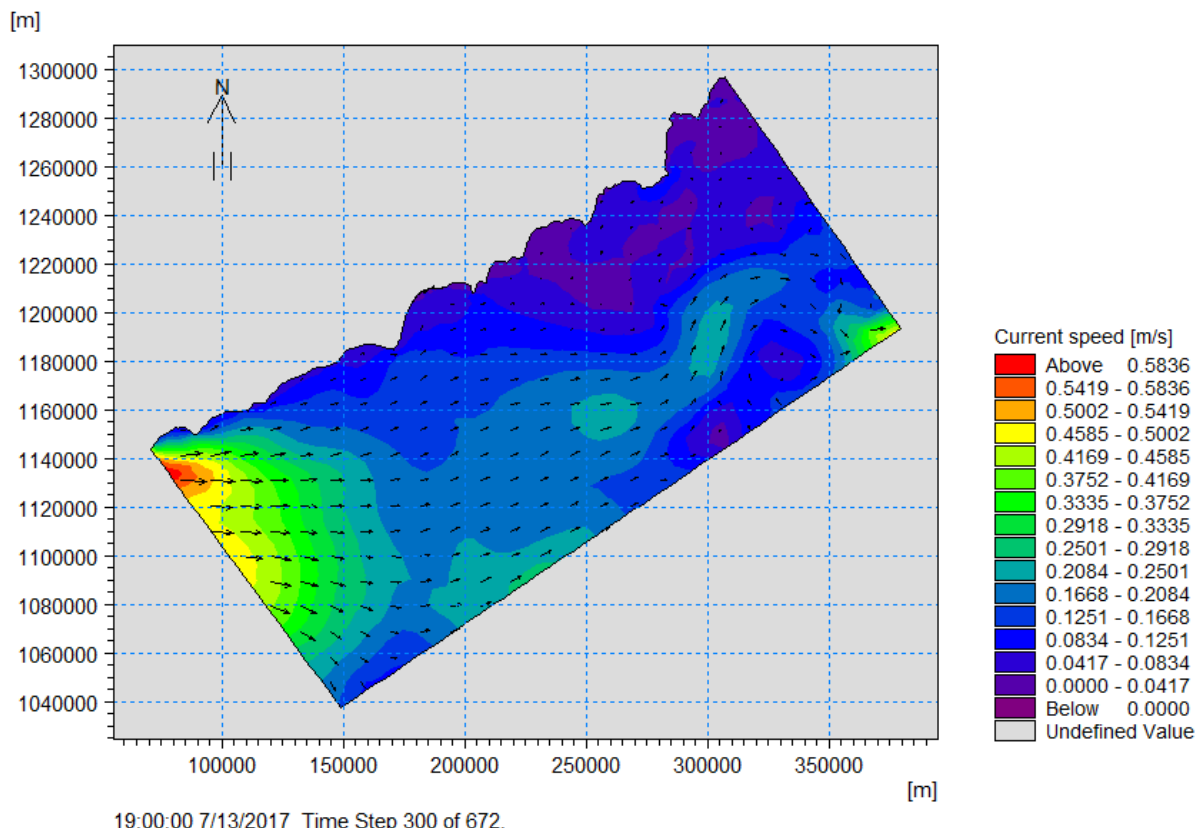

Hình 15. Trường vận tốc dòng chảy dưới ảnh hưởng của gió Tây Nam. 
- Dòng chảy dưới ảnh hưởng của sóng Tây Nam: Trong trường hợp này (Hình 16), ta thấy dưới ảnh hưởng của sóng truyền theo hướng Tây sinh ra dòng chảy dịch chuyển nhiều về hướng Đông Bắc, vận tốc dòng chảy khu tại khu vực nghiên cứu rất nhỏ, dao động khoảng $0,015-0,18 \mathrm{~m} / \mathrm{s}$, khi vào gần bờ biển Đồi Dương, dòng chảy có sự đổi hướng, dịch chuyển đến Tây Bắc.

- Dòng chảy dưới ảnh hưởng của triều trong mùa gió Tây Nam: Khi chỉ xét đến ảnh hưởng của thủy triều, kết quả dòng chảy vào mùa gió Tây Nam cho thấy ở khi vực ngoài khơi, dòng chảy có xu hướng dịch chuyển về 2 hướng chính là Đông Bắc và Tây Nam. Khi tiến vào bờ, hướng dòng chảy dịch chuyển qua hướng Tây Bắc và Đông Nam.

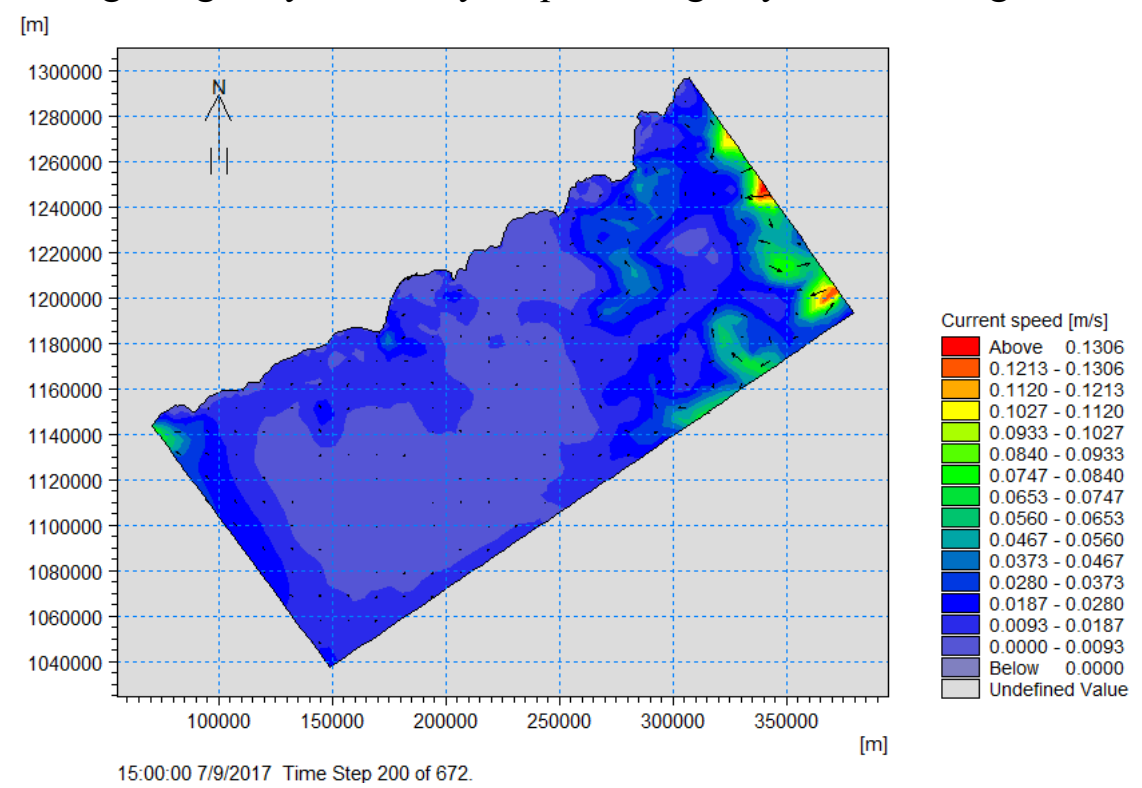

Hình 16. Trường vận tốc dòng chảy dưới ảnh hưởng của sóng vào mùa Tây Nam.

- Dòng chảy tổng hợp trong mùa gió Tây Nam: Kết quả mô phỏng dòng chảy tổng cộng được thể hiện trên Hình 17-18.

Dòng chảy do sóng
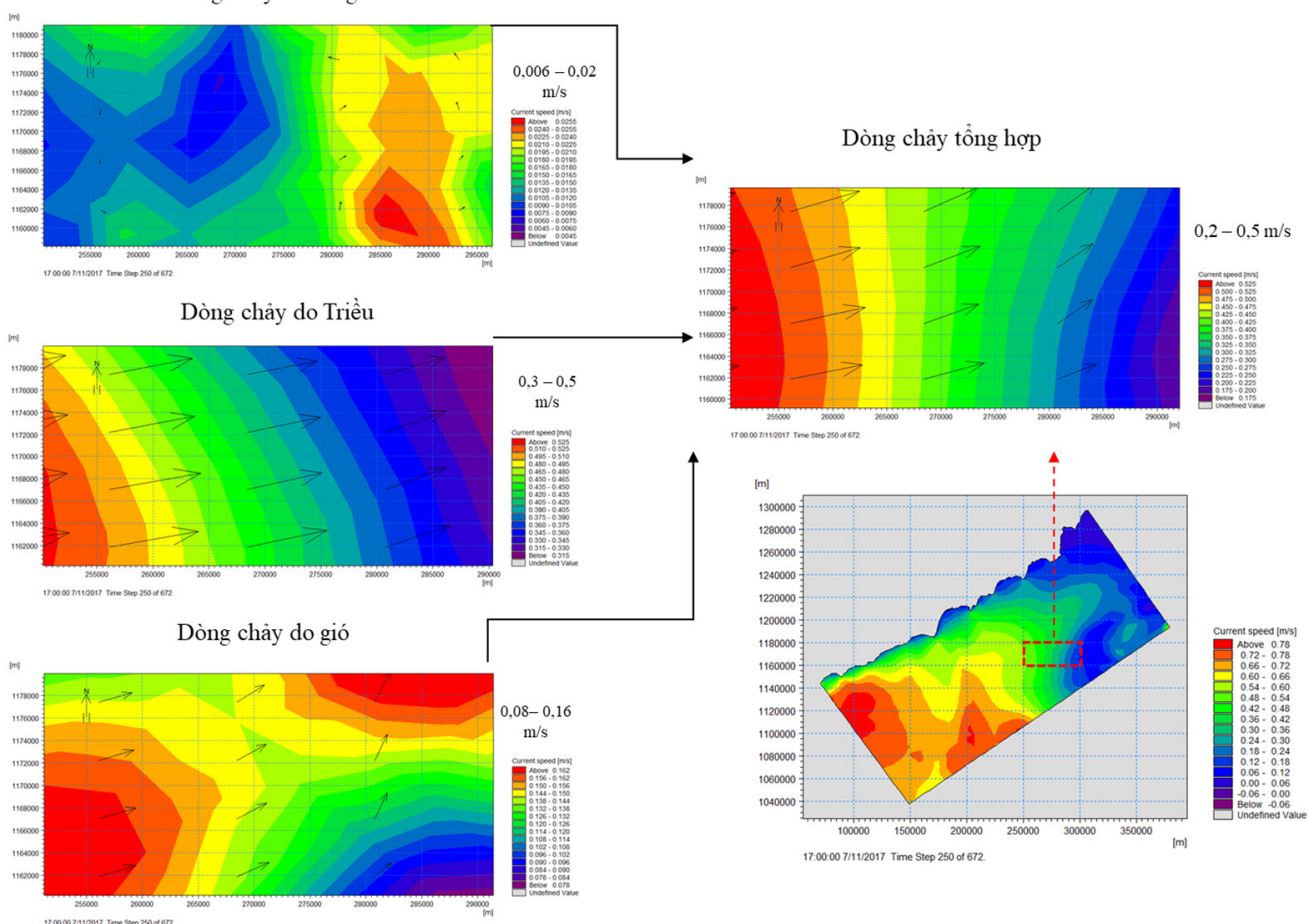

Hình 17. Ảnh hưởng của dòng chảy thành phần tại khu vực ngoài khơi vào gió mùa Tây Nam. 


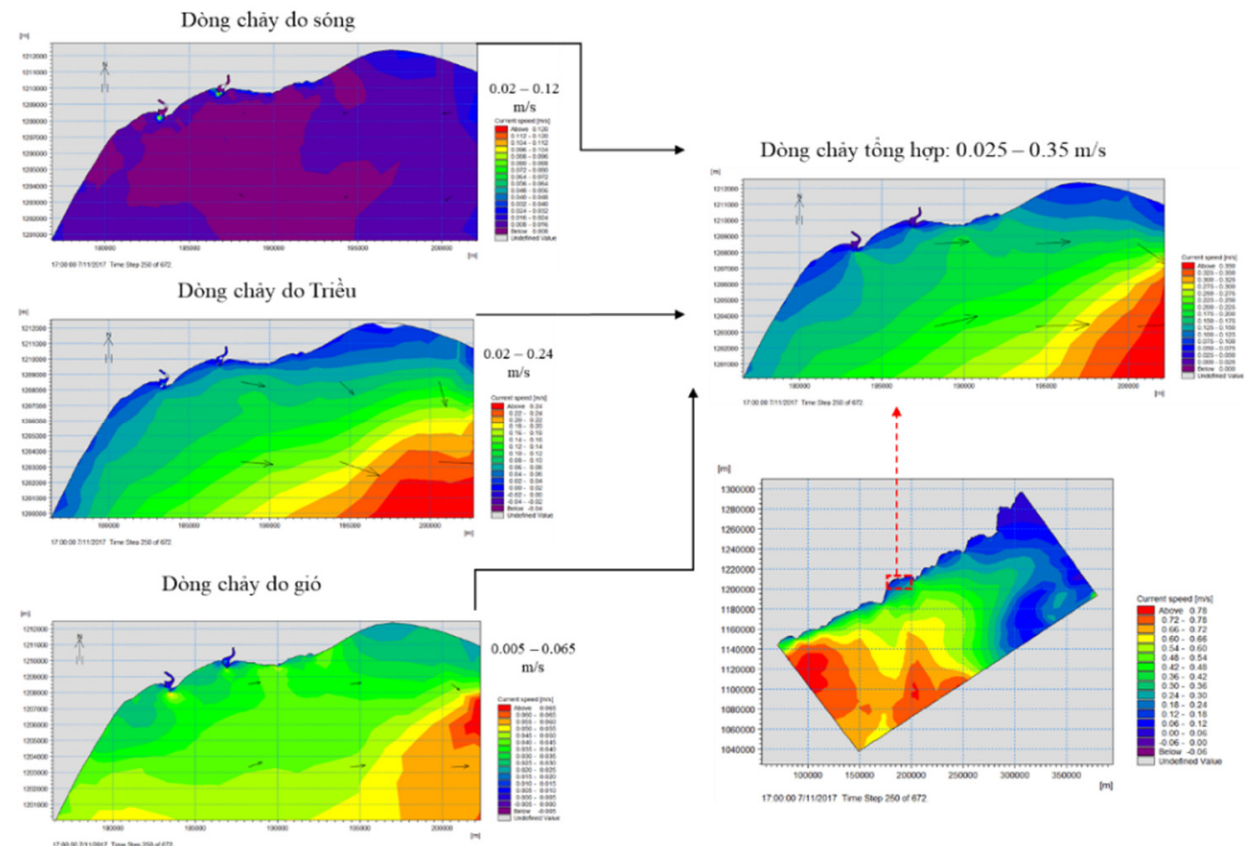

Hình 18. Ảnh hưởng của dòng chảy thành phần tại khu vực ven bờ vào gió mùa Tây Nam.

Tương tự vào mùa gió Đông Bắc, dòng chảy tại khu vực nghiên cứu vào mùa gió Tây Nam chịu ảnh hưởng nhiều nhất bởi dòng triều. Dưới ảnh hưởng của sóng truyền theo hướng Tây sinh ra dòng chảy rất nhỏ, vận tốc chỉ khoảng $0,006-0,02 \mathrm{~m} / \mathrm{s}$ ở khu vực ngoài khơi, vận tốc dòng chảy sóng ở khu vực ven bãi biển Đồi Dương cao hơn, đạt khoảng $0,02-0,12 \mathrm{~m} / \mathrm{s}$. Dòng chảy sinh ra do gió đạt vận tốc 0,08 đến $0,16 \mathrm{~m} / \mathrm{s}$ ở ngoài khơi, vô bờ giảm dần $0,005-$ $0,065 \mathrm{~m} / \mathrm{s}$. Thủy triều gây nên vận tốc dòng chảy khá lớn, đạt $0,3-0,5 \mathrm{~m} / \mathrm{s}$ ở ngoài biển, và $0,02-0,24 \mathrm{~m} / \mathrm{s}$ ở khu vực gần bờ. Dòng chảy tổng hợp có xu hướng dịch chuyển từ phía Tây Tây Nam lên hướng Đông Đông Bắc với vận tốc $0,2-0,5 \mathrm{~m} / \mathrm{s}$.

Để so sánh chi tiết hơn tốc độ dòng chảy vào mùa gió Đông Bắc và mùa gió Tây Nam, bài báo lựa chọn 10 vị trí nằm theo hướng thẳng góc với đường bờ, đại diện cho cả 3 vùng của lưới tính (từ phía bãi biển Đồi Dương ra ngoài khơi) như Hình 19 để trích xuất kết quả từ mô hình.

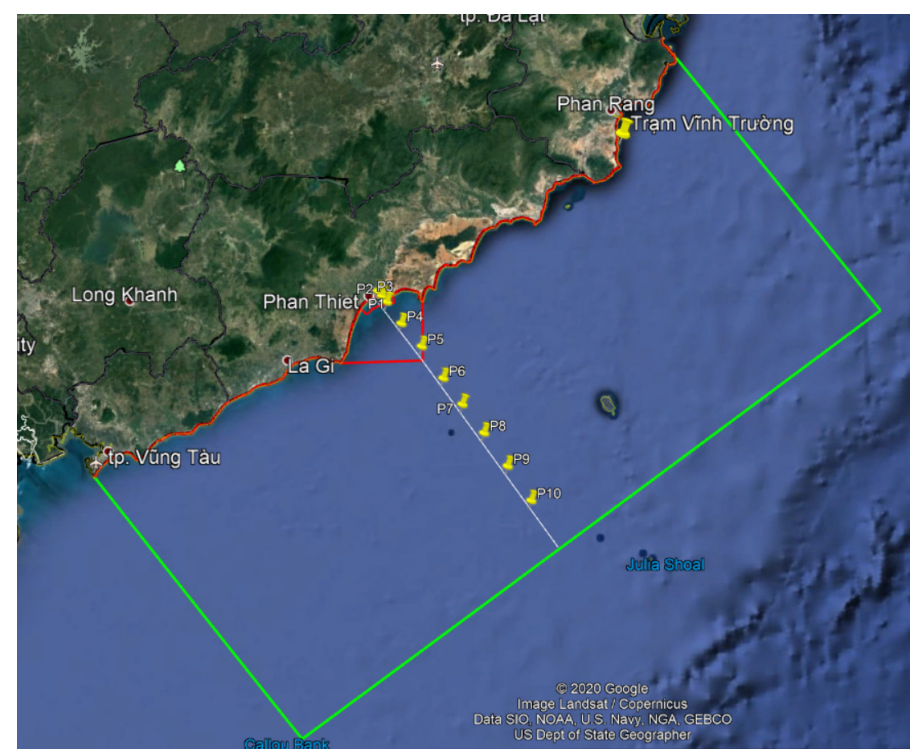

Hình 19. Vị trí các điểm trích xuất giá trị vận tốc dòng chảy nằm theo hướng thẳng góc với đường bờ, đại diện cho cả 3 vùng của lưới tính. 


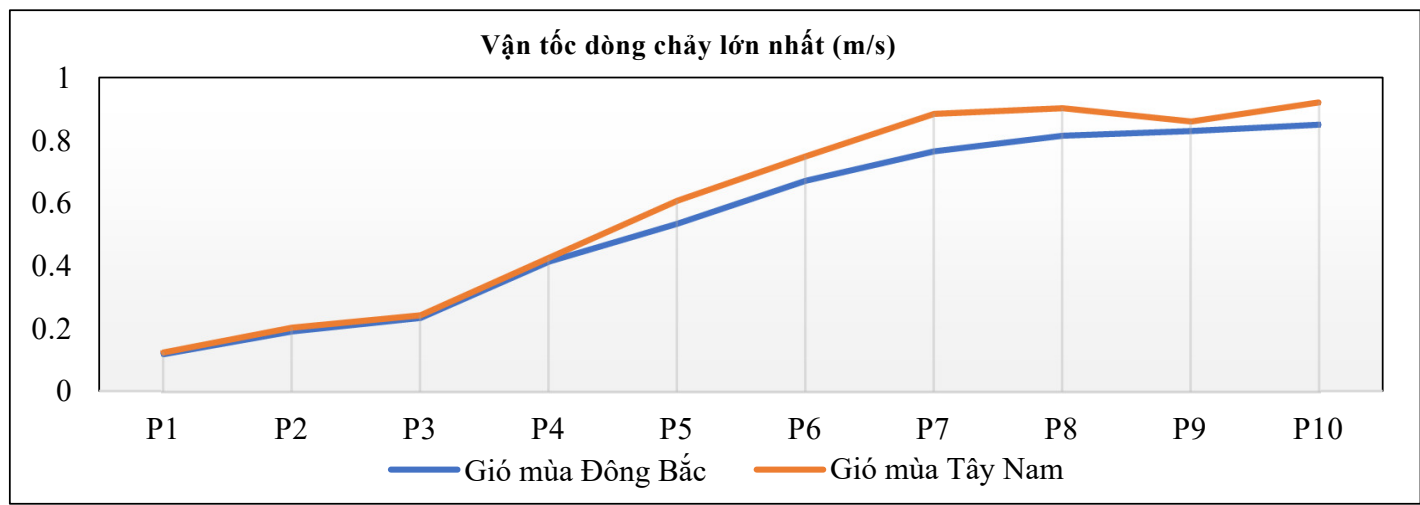

Hình 20. Biểu đồ so sánh giá trị vận tốc dòng chảy lớn nhất tại các vị trí.

Hình 20 thể hiện giá trị vận tốc lớn nhất của dòng chảy tại các vị trí trích xuất vào gió mùa Đông Bắc và Tây Nam. Ở cả 2 mùa, vận tốc dòng chảy có xu hướng lớn dần khi dịch chuyển từ bờ ra ngoài khơi.

\section{Kết luận}

Bằng việc sử dụng phương pháp mô hình toán, cụ thể là mô hình MIKE 21 với mô đun $\mathrm{SW}$ và $\mathrm{HD}$, nghiên cứu đã tính toán được sóng và dòng chảy tại khu vực bãi biển Đồi Dương.

Mô hình MIKE cùng với việc xác định các điều kiện biên cho mô hình để nghiên cứu động lực sóng và dòng chảy trong hai mùa gió Đông Bắc và Tây Nam tại khu vực bãi biển Đồi Dương đạt kết quả khả quan thông qua các kết quả hiệu chỉnh và kiểm định với số liệu thực đo tại trạm Vĩnh Tường (NSE và $\left.\mathrm{R}^{2}>0,8\right)$. Từ những kết quả đó, nghiên cứu này có thể đưa ra những kết luận sau:

+ Chế độ sóng khu vực nghiên cứu chịu ảnh hưởng nhiều vào chế độ gió tại khu vực. Sóng gió trong vùng cửa sông không lớn do đặc điểm địa hình. Vào tháng 1 , gió chủ yếu theo hướng Đông Bắc, vì thế sóng tới từ ngoài khơi truyền vào cũng theo hướng Đông Bắc là chủ yếu, tuy nhiên hướng sóng không tác động vào khu vực ven bờ nên độ cao sóng khu vực ven bờ vùng nghiên cứu khá nhỏ. Vào tháng 7 , sóng chủ yếu theo hướng Tây Nam với độ cao sóng có nghĩa nhỏ hơn so với tháng 1.

+ Trường dòng chảy tại khu vực nghiên cứu cũng khá phức tạp, vận tốc và hướng dòng chảy phụ thuộc vào nhiều yếu tố như gió, sóng, thủy triều, địa hình,... Dòng chảy tại bãi biển Đồi Dương là tổng hợp của dòng chảy gió, dòng triều và dòng chảy sóng. Kết quả tính toán cho thấy, dòng triều tuần hoàn có vai trò quan trọng quyết định đến tính chất chung của dòng chảy tổng hợp. Dòng chảy tại khu vực bãi biển Đồi Dương (Vùng 1) có xu hướng tương tự chế độ dòng chảy vịnh Phan Thiết (Vùng 2), tuy nhiên vận tốc dòng chảy khi vào gần bờ nhỏ hơn so với phía ngoài biển.

Chế độ dòng chảy mô phỏng được trong khu vực này phần nào phản ánh phù hợp với quy luật động lực học của bãi biển Đồi Dương. Các kết quả nghiên cứu trên góp phần làm rõ chế độ dòng chảy khu vực này và phục vụ cho bài toán xói lở cũng như bài toán lan truyền ô nhiễm ven biển.

Kết quả tính toán dòng chảy tổng hợp tại khu vực nghiên cứu có những sai số nhất định, đó là sai số tổ hợp của mô hình sóng, sai số của mô hình tính toán dòng chảy và có cả những sai số trong quá trình quan trắc dữ liệu thực đo. Mặc dù có những sai số tổ hợp nhưng kêt quả tính toán dòng chảy tổng hợp từ mô hình Mike 21 khá phù hợp với đặc trưng chế độ thủy động lực tại khu vực.

Nghiên cứu mới chỉ dừng ở việc ứng dụng mô đun thủy động lực học và mô đun phổ sóng ven bờ trong phân tích tính toán dòng chảy và sóng mà chưa sử dụng mô đun hình thái học tính toán diê̂n biến lòng dẫn nên kết quả mới dừng ở mức đánh giá chung mang tính định hướng và sẽ được bổ sung trong các nghiên cứu tiếp theo. 
Đóng góp của tác giả: Xây dựng ý tưởng nghiên cứu: N.K.P., P.T.M.D., N.N.T.; Lựa chọn phương pháp nghiên cứu: N.K.P., P.T.M.D., N.N.T.; Xử lý số liệu: P.T.M.D.; Mô hình hóa: P.T.M.D.; Phân tích kết quả: P.T.M.D.; Chỉnh sửa bài báo: P.T.M.D., N.K.P.

Lời cảm ơn: Nghiên cứu này được thực hiện dưới sự hỗ trợ của đề tài "Nghiên cứu tính toán sự xuất hiện dòng Rip vùng ven biển Nam Trung Bộ, áp dụng cho bãi biển Đồi Dương tỉnh Bình Thuận" mã số TNMT.2018.06.10.

Lời cam đoan: Tập thể tác giả cam đoan bài báo này là công trình nghiên cứu của tập thể tác giả, chưa được công bố ở đâu, không được sao chép từ những nghiên cứu trước đây; không có sự tranh chấp lợi ích trong nhóm tác giả.

\section{Tài liệu tham khảo}

1. Sở Văn hóa, Thể thao và Du lịch Bình Thuận. Đề án phát triển du lịch sinh thái tỉnh Bình Thuận.

2. Manh, D.; Yanagi, T. A study on the residual flow in the gulf of tonkin. J. Oceanogr. 2000, 56, 59-68. https://doi.or.g/10.1023/A:1011162524466.

3. Phùng, N.K.; Nga, D.T. Nghiên cứu sự thay đổi chế độ dòng chảy và khả năng bồi xói khi tiến hành nạo-vét luồng tàu ở cảng Dung Quất, Tỉnh Quảng Ngãi. Tạp chí Khi tương Thüy văn 2010, 598, 39-44.

4. Bảy, N.T.; Phùng, N.K. Nghiên cứu chế độ dòng chảy khu vực ven biển Cửa Lấp Vũng Tàu. Tạp chí Khí tương Thủy văn 2009, 609, 7-13.

5. Vĩnh, V.D.; Cự, N.Đ.; Thạnh, T.Đ. Ảnh hưởng của đập Hòa Bình đến phân bố trầm tích lơ lửng vùng ven bờ châu thổ sông Hồng. Kỷ yếu Hội nghị Khoa học và Công nghệ biển lần thứ 5, Địa chất, Địa lý- Địa vật lý 2011, 3, 465-475.

6. Vĩnh, V.D.; Lân, T.Đ.; Tú, T.A.; Anh, N.T.K. Mô phỏng ảnh hưởng của mực nước biển dâng đến biến động địa hình đáy vùng ven bờ cửa sông Mê Kông. Tạp chi Khoa họ và Công nghệ Biển 2015, 15, 139-149.

7. Bay, N.T.; Kien, C.L. Studying of riverbank erosion model to calculate the river morphology under the effect of bed erosion. Proceedings of 80 the $9^{\text {th }}$ National Conference in Mechanics, Ha Noi University of Technology, Vietnam, 8-9/12/2012.

8. Phùng, N.K.; Khôi, Đ.N. Đánh giá biến đổi đáy ven bờ biển Rạch Giá. Tạp chí Phát triển Khoa học \& Công nghệ 2009, 12, 15-25.

9. Sáo, N.T.; Anh, T.N.; Sơn, N.T.; Giang, Đ.V. Đánh giá tác động công trình đến bức tranh thủy động lực khu vực cửa sông ven bờ Bến Hải, Quảng Trị. Tạp chí Khoa học ĐHQGHN, Khoa hoc Tự nhiên và Công nghệ 2010, 26, 435-442.

10. Việt, N.T. Nghiên cứu chế độ thủy động lực học và vận chuyển bùn cát vùng cửa sông và bờ biển Vịnh Nha Trang, tỉnh Khánh Hòa, 2013-2014.

11. DHI. MIKE 21, Spectral Wave mô đun, Scientific Documentation, 2012.

12. Komen, G.L.; Cavaleri, L.; Doneland, M.; Hansselmann, K.; Hansselmann, S.; Janssen, P.A.E.M. Dynamics and modelling of ocean waves. Cambrige University Press, UK, 1994, 560. https://doi.or.g/10.1017/CBO9780511628955.

13. DHI. MIKE 21 \& MIKE 3 Flow Model FM. Hydrodynamic Mô đun. Scientific documentation, 2012.

14. Ikeda, S.; Parker, G.; Sawai, K. Bend theory of river meanders. Part 1. Linear development. J. Fluid Mech. 1981, 112, 363-377.

15. Moriasi, D.N.; Gitau, M.W.; Pai, N.; Daggupati, P. Hydrologic and water quality models: Performance measures and evaluation criteria. Trans. ASABE 2015, 58, 1763-1785. 


\title{
Research on flow regime at Doi Duong beach, Binh Thuan Province
}

\author{
Phung Thi My Diem ${ }^{1,2 *}$, Ngo Nam Thinh ${ }^{1,2}$, Nguyen Ky Phung ${ }^{3}$ \\ 1 Ho Chi Minh City University of Natural Resources and Environment; \\ diemptm@hcmunre.edu.vn; nnthinh@hcmunre.edu.vn \\ 2 VNUHCM-University of Science; diemptm@hcmunre.edu.vn; \\ nnthinh@hcmunre.edu.vn \\ 3 Ho Chi Minh City Department of Science and Technology; kyphungng@gmail.com
}

\begin{abstract}
The Mike $21 \mathrm{SW}$ wave model (Spectral Waves) and the hydraulic model Mike 21 HD FM (Hydro Dynamic Flow Model) were used in the paper to calculate the coastal current and wave fields in Doi Duong beach, Phan Thiet, Binh Thuan Province. Mike 21 SW wave model and Mike 21 HD FM are calibration and accreditation with real measured data with quite good correlation coefficient. The results of the wave field calculation are input conditions for the Mike 21 HD FM synthetic current model. The results of wave field calculation in Doi Duong beach area show that the significant wave height in northeast monsoon season is about $0.9-1.3 \mathrm{~m}$, with the wave direction in the Northeast direction, in the southwest monsoon about $04-0.7 \mathrm{~m}$ with the wave direction in the southwest direction. As for the flow velocity, the calculation results show that the current velocity at the coast of Doi Duong is quite small, reaching about $0.025-0.35 \mathrm{~m} / \mathrm{s}$ in the southwest monsoon season and $0.02-0.3 \mathrm{~m} / \mathrm{s}$ for northeast monsoon season. Hydrodynamic calculation results show that flow in Doi Duong beach area is strongly influenced by tides. The study also serves as the basis for solutions to minimize negative impacts on the coastal areas caused by the flow, contributing to the orientation of socioeconomic development in the study area.
\end{abstract}

Keywords: Mike 21 SW; Mike 21 HD FM; Aggregate flow; Waves; Doi Duong beach. 